\title{
Cumhurun Haber-i Vâhid Çerçevesinde Umûmu'l-Belvâya İlişkin Değerlendirmeleri
}

\author{
Evaluation of the Jumhur (Majority of Scholars) on Umum al-Balwa in the Framework of
} Khabar Wahid

\section{Sadrettin BUĞDA}

\section{Dr. Öğr. Üyesi, Muş Alpaslan Üniversitesi, İslami İlimler Fakültesi, Temel İslam Bilimleri Bölümü, İslam Hukuku Anabilim Dalı} Assist. Prof. Dr., Mus Alpaslan University, Faculty of Islamic Science, Department of Basic
Islamic Sciences Islamic Law Department

\author{
Mus/TURKEY \\ http://orcid.org/ 0000-0002-6135-8570
}

Doi: $10.34085 /$ buifd.1026842

Öz

Umûmu'l-belvâ ilkesi usûl disiplininde geniş bir yelpazeye sahiptir. Zira usûl eserlerinde umûmu'l-belvâ; âhâd haber, sükûtî icmâ', kıyas, istihsân ve sedd-i zerâ'i gibi naklî ve aklî delillerle ilişkili olarak geniş bir şekilde ele alınmaktadır. Usûlcülerin umûmu'l-belvâ hususunda çokça tartıştıkları meselelerden biri âhâd haberin tenkidinde umûmu'l-belvânın bir kriter olarak kabul edilip edilmeme konusudur. Usûl âlimleri şer'î amelî meselelerde haber-i vâhidin delil teşkil etmesi için birtakım şartlar ileri sürmüşlerdir. Âlimler, haber-i vâhid hususunda ortaya konan bazı şartlar üzerinde ittifak ederken bazısında ise ihtilaf etmişlerdir. Üzerinde ihtilaf edilen şartlardan bir de umûmu'l-belvâ'dır. Hanefi usûlcülerin büyük çoğunluğu, herkesin bilmesi gereken şer ‘î amelî konularda haber-i vâhidin bir delil olmayacağını iddia etmişlerdir. Dolayısıyla onlara göre haber-i vâhidin kabul şartlarından biri de umûmu'l-belvâ olarak nitelenen olaylarla alakalı olmaması gerektiğidir. Mezkûr âlimlerin öne sürdükleri bu şart, cumhur tarafından kabul görmemiştir. Bu çalışmada haber-i vâhidin genel çerçevesi ve umûmu'l-belvânın mahiyeti ele alındıktan sonra umûmu'l-belvâya dair konularda varid olan haber-i vâhidin delil değeri hususunda farklı görüşlere sahip olan âlimlerin söz konusu mesele hakkındaki düşünceleri delilleriyle beraber sunulmasını amaçlamaktadır.

Anahtar kelimeler: Fıkıh usûlü, Âhâd haber, Haber-i vâhid, Umûmu'l-belvâ, Bilgi, Delil.

\section{Abstract:}

The principle of Umum al-Balwa has a wide spectrum in the discipline of usûl since in usûl works Umum alBalwa is discussed extensively in relation to the naqlî and aqlî adillah such as the khabar âhâd, suqutî ijmâ' , qiyas, istihsân and sedd-i zerâ' i. One of the issues that the usûlists have discussed a lot about Umum al-Balwa is whether it can be accepted as a criterion in the tanqeed of khabar âhâd or not. Usûl ulema have set forth some conditions in order for the khabar âhâd to constitute dalil in sharî amalî matters. While ulema agreed on some of the conditions put forward regarding the khabar wahid, they disagreed on some of them. One of the conditions on which there is ikhtilaf is Umum al-Balwa. The vast majority of Hanafi ulema have argued that the khabar wahid cannot be a dalil about sharî amalî matters which everyone should know. Therefore, to them, one of the conditions of acceptance of the khabar wahid is that it must not be related to the events described as Umum alBalwa. This condition, stated by the aforementioned ulema, was not accepted by the public. In this study, after the general framework of the khabar wahid and the nature of Umum al-Balwa are discussed, it is aimed to reveal the opinions of the holders of both views on the issue in question, together with their adillah.

Keywords: Fiqh usûl, Khabar âhâd, Khabar Wahid, Umum al-Balwa, Knowledge, Dalil.

\section{GİRIŞ}

Sahabe, Peygamber (s.a.v.) döneminde karşılaştıkları sorunların çözümü için Peygamber'e (s.a.v.) müracaat etmekteydiler. Başka bir ifadeyle sahabe döneminde çözüm mercii bizatihi Peygamber'di. Peygamber'in (s.a.v.) vefatı ile birlikte birebir başvurulacak ve sorunları çözecek mercii de ortadan kalkmış oldu. Peygamber'in (s.a.v.) vefatından sonra çözüm mercii olarak Peygamber'in (s.a.v.) şahsiyeti yerini Kur'ân ve Sünnetteki naslara bırakmıştır. İslam’ın evrenselliğinin bir gereği olarak Kur'ân ve Sünnetin bütün çağlara ve nesillere ulaşması; Müslüman toplumun sorunlarının çözümünde kaynak olması hasebiyle Kur'ân'ın yanında Sünnetin de muhafaza edilmesi gereklidir. Bu bilinçten hareketle sahabe Peygamber'in (s.a.v.) vefatından sonra Kur'ân'ın yanında Sünnete bağlılığını sürdürmüş ve kendisinden sonra gelen nesillerin de buna ittiba etmeleri gayesiyle sünnetin korunması için gayret göstermişlerdir. 
Hadis literatüründe birinci halka olarak telakki edilen sahabe Peygamber'in (s.a.v.) döneminde olduğu gibi ${ }^{1}$ onun vefatından sonra da haber-i vâhid ile amel etmişlerdir. ${ }^{2}$ Ancak Peygamber' in (s.a.v.) vefatından sonra kendilerine haber getiren kişinin vehme düşme ihtimali bulunduğunda başka kişilerin şahitliğine de başvurmuşlardır. ${ }^{3}$ Buradan hareketle şunu söylemek mümkündür: Hadis kritiği daha ilk halkadan itibaren başladığı görülmektedir. Hz. Âiş̧e'nin (r.a.) istidrâkatları bunun en önemli göstergelerinden biridir.

Fıkıh usûlü âlimlerinin ve hadisçilerinin hadis ile ilgili tenkîd faaliyetleri rivâyet ve râviye yönelik olup hadislerin Peygamber'e aidiyetinin doğruluğunu tespit etme çabasıdır. Yapılan tenkîd faaliyeti bizatihi Peygamber'in (s.a.v) söz, fiil ve takrirlerine yönelik değildir. Zira Peygamber (s.a.v.) masumdur ve onun söz ile eylemleri ilâhî vahye dayanmaktadır. Onun sözlerinde yalan ve vehim söz konusu olmadığı da bilinen bir hakikattir. Dolayısıyla Peygamber'in (s.a.v.) bizatihi söz ve eylemlerini kritik etmek caiz değildir.

Usûl disiplininde râvi yoğunluğuna göre hadis, farklı kategorilere ayırt edilmiştir. Hanefi âlimlerin büyük çoğunluğuna göre râvi yoğunluğu itibariyle hadis; mütevâtir, meşhûr ve âhâd şeklinde üçe ayrılmaktadır. Mütekellim usûlcülerin genel kabulüne göre ise hadis, ilk etapta mütevâtir ve âhâd şeklinde ikiye ayrılmaktadır. Ayrıca âhâd haber de kendi içinde müstefîd/meşhûr ve haberu'l-vâhid şeklinde kategorize edilmektedir. Söz konusu hadis kısımlarının biri olan haberu'l-vâhidin ameli gerektirmesi için de birtakım şartlara haiz olması gerekir. Bu çalışmada haberu'l-vâhid ile amel edilebilmesi için ileri sürülen umûmü'l-belvâ kriteri üzerinde durulacaktır.

\section{Haber-i Vâhid ile Amel Etmenin Bir Şartı Olarak Haberin Umûmu'1-Belvâya Dair Konularda Varid Olmaması Şartı}

Umûmu'l-Belvânın tanımı ve mahiyetine geçmeden önce kısa bir şekilde haber-i vâhide değinmekte yarar vardır. Zira umûmu'l-belvâ, usulün birçok konusuyla ilintili olduğu gibi haber-i vâhid ile ilintili olup bazı âlimlere göre onun kabul veya reddinde önemli bir faktördür.

\subsection{Haber-i Vâhidin Tanımı ve Şatları}

Usûl âlimleri kendi anlayışlarına göre haber-i vâhidin tanımını farklı şekillerde yapmışlardır. Yapılan tanımlardan biri "(Râvi yoğunluğu ve bilgi değeri açısından) tevatür derecesine varamayan haber" şeklindeki tanımdır. ${ }^{4}$ Pezdevî (öl. 482/1089) ise haber-i vâhidi "Bir, iki veya daha fazla kişinin rivâyet ettiği ancak râvi sayısı meşhûr ve mütevâtir sayısına varmayan haberdir." şeklinde tanımlamakta, akabinde bu tür haberlerin ameli gerektirip ancak kat'î bilgiyi gerektirmediğini belirtmektedir. ${ }^{5}$ Haber-i vâhid ile ilgili yapılan tanımlar dikkate alındığında derli toplu bir şekilde onu şöyle tanımlamak da mümkündür: Bir veya daha fazla kişinin rivayet ettiği, ancak râvi yoğunluğu itibariyle ve bilgi ile delil değeri yönüyle tevâtür derecesine ulaşmayan haberdir.

Haber-i vâhid ile istişhâd edebilmek için haberin ve onu rivayet eden râvinin birtakım şartlara haiz olması gerekir. Söz konusu şartların bazısı bütün mezhep âlimleri tarafından kabul görürken bazısı ise tartışmalıdır. İttifak ile kabul görülen şartlar şunlardır:

\footnotetext{
${ }^{1}$ Bk. Ebû Abdullâh Muhammed b. İdrîs eş-Şâfiî, er-Risâle, thk. Ahmed Muhammed Şâkir (Mısır: Matba'atu Mustafâ el-Bâbî elHalebî, 1358/1940), 401-406; Ebû Bekir Ahmed b. Alî er-Râzî el-Cessâs, el-Fuṣ̂l fi'l-ușûl, thk. Ucayl Câsim en-Neşemî (Kuveyt: Vizâretu'l-Evkâf, 1414/1994), 3/81-82; Ebû Ya'lâ Muhammed b. el-Hüseyn b. Muhammed b. Halef el-Ferrâ', el- 'Udde fì ușûli'l-fikh , nşr. Ahmed b. Ali Seyr el-Mübârekî (b.y.: y.y, 1410/1990), 3/859; Ebû Bekr Ahmed b. Alî b. Sâbit el-Hatîb el-Bağdâdî, el-Fakîh ve'l-mütefakkih, thk. Ebû Abdirrahmân Âdil b. Yûsuf el-Garâzî (Suudi Arabistan, Dâru İbni'l-Cevzî, 1421), 1/238.

2 Bk. Ebû Zeyd Abdullâh b. Ömer b. Îsâ ed-Debûsî, Takoîmu'l-edille fì ușûli'l-fikhh, thk. Halîl Muhyiddîn el-Meys (Beyrut: Dâru'lKutubi'l-‘ìlmiyye, 2001) 173-174; Ebu'l-Hüseyn Muhammed b. Alî b. Tayyib el-Basrî, el-Mu 'temed fì uṣ̂uli'l-fikh, thk. Halîl el-Miss (Dâru'l-Kutubi'l-'̇̇lmiyye, 1043), 2/18; Ebu'l-Vefâ Alî b. Akîl b. Muhammed b. Akîl el-Bağdâdî, el-Vâdlh fi ușûli'l-fikh, Abdullâh b. Abdulmuhsin et-Türkî (Beyrut: Müessesetu'r-Risâle, 1420/1999), 4/372-376; Ebü'l-Hasen Seyfuddîn Alî b. Muhammed b. Sâlim el-Âmidî, el-ịhkâm fì uṣûli'l-ahkâm, thk. Abdurrazzâk Afîfí (Beyrut: el-Mektebu'l-İslâmî, 1402), 2/64-66; Muhammed b. Ahmed b. Abdulazîz b. Alî İbnü'n-Neccâr el-Fütûhî, Şerḥu'l-Kevkebi'l-münîr, thk. Muhammed Zuhayl - Nezîr Hamâd (Riyad: Mektebetu'l'Ubeykân, 1413/1993) 2/369-374.

${ }^{3}$ Bk. Basrî, el-Mu 'temed, 2/115-116; İbn Akîl, el-Vâdı̆ fî uṣ̂uli'l-fiḳh, 4/379-380.

${ }^{4}$ Ebû İshâk İbrâhîm b. Alî eş-Şîrâzî, Şerhu'l-Luma ', thk. Abdulmecîd et-Türkî (Beyrut: Dâru'l-Garbi'l-İslâmî, 1408/1988), 2/578.

${ }^{5}$ Ebu'l-Hasan Ebu'l-Usr Alî b. Muhammed el-Pezdevî, Kenzü'l-vüsûl ilâ ma 'rifeti'l-ușûl (Karaçi: Mir Muhammed Kütüphanesi Merkez-1 İlim ve Adâb, ts.), 152.
} 
a) Râvi, bâliğ ve akıllı olmalıdır. Ergenlik çağına ermemiş küçük çocukların ve ergenlik çağına ulaşıp ancak aklî melekeleri olmayan kişilerin rivayet ettikleri haberlerin delil değeri yoktur. ${ }^{6}$ Zira bunların yalan söylemelerinden dolayı mesul olmadıkları için yalan haberde bulunma ihtimalleri mümkündür. ${ }^{7}$

b) Râvi Müslüman olmalıdır. Müslüman olmayan kişinin rivayeti ile amel edilmez. ${ }^{8}$ Müslüman olmayan râvinin Allah korkusu olmaması nedeniyle yalandan sakınmaması ve vereceği habere yalan katma ihtimali ön plana çıkması gerekçesiyle onun vereceği haber ile amel edilmemektedir.

c) Râvi adil olmalıdır. Adalet sahibi olmak günahlardan kaçınmak ve takva sahibi olmak anlamındadır. Söz konusu vasıflara sahip olmayan kişilerin rivayeti kabul edilmez. ${ }^{9}$

d) Râvi sadık olmalıdır. Güvenilir olamayan ve yalan konuşan kişilerin rivayetleri makbul değildir. ${ }^{10}$

e) Râvi zapt ehli olmalıdır. Râvi rivayet ettiği konuyu rivayet zamanına kadar onu hafızasında koruyabilme ve işittiği sözlerden ne kast edildiğini kavrayabilme yeteneğine sahip olmalıdır. Zapt ehli olmayan kişilerin rivayetiyle istişhâd edilmez. ${ }^{11}$

Usûlcülerin üzerinde ihtilaf ettikleri şartlar da şunlardır. a) Hadisin senedi muttasıl olmalıdır. Bu şartı ileri süren Şafî̀'dir (öl. 204/820). Şafiî bu şartı mutlak olarak ileri sürmemektedir. Ona göre mürsel hadis bazı şartlara haiz olduğunda onunla da amel edilir. ${ }^{12}$ Cumhura göre ise senedin muttasıl olması şart değildir. b) Haber-i vâhid, Medine ehlinin uygulamasına aykırı olmamalıdır. ${ }^{13}$ c) Haber-i vâhid, sübutu kesin olan şer'î esaslara ve kıyasa aykırı olmamalıdır. ${ }^{14} \mathrm{Bu}$ iki şartı ileri süren Malikî âlimlerdir. Karâfî ayrıca İmam Mâlik'in haber-i vâhidin kabul edilebilmesi için râvinin fakih olması şartını ileri sürdüğünü ifade etmektedir..$^{15} \mathrm{~d}$ ) Râvi rivayetin aksiyle amel etmemiş veya fetva vermemiş olmalıdır. ${ }^{16}$ e) Râvi fakih değil ise onun rivayet ettiği haber, şer'î esaslara ve kıyasa aykırı olmamalıdır. ${ }^{17}$ f) Haber-i vâhid umûmu'l-belvâda varid olmamalıdır. Yani haber-i vâhid herkesi ilgilendiren ve hükmü her kes tarafından bilinmesi gereken konularda varid olmamalıdır. ${ }^{18} \mathrm{Bu}$ son üç şart da Hanefî âlimler tarafından ortaya konan şartlardır. Karâfî, Mâlikî âlimlerin büyük çoğunluğunun da râvi rivayetin aksiyle amel etmeme şartını ileri sürdüklerini belirtmektedir. ${ }^{19}$

\subsection{Umûmu'l-Belvânın Tanımı}

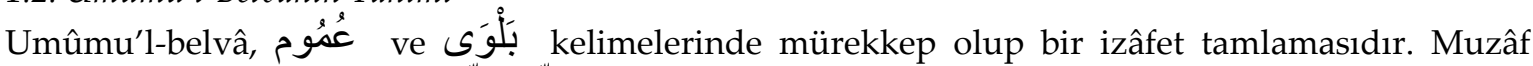
konumunda olan يعمّ- عمّ kelimesilin mastarı olup “yaygın olmak, içine almak, şamil gelmek

\footnotetext{
${ }^{6}$ Şîâazî, Şerhu'l-Luma ', 2/630; İmâmü'l-Haremeyn Ebu'l-Me‘âlî Abdulmelik b. Abdillâh b. Yûsuf el-Cüveynî, et-Telhîs fì uṣûli'lfikhh, thk. Abdullah Culim en-Nebâlî - Beşîr Ahmed el-Ömerî (Beyrut: Dâru'l-Beşâiri'l-İslâmî, ts.), 2/350.

7 Sa`duddîn Mes'ûd b. Fahriddîn Ömer b. Burhâniddîn et-Teftâzânî, Şerhu't-telvîh ala't-Tavdîh (Mısır: Mektebetu Sabîh, ts.), 2/11.

8 İmâmü'l-Haremeyn Ebu'l-Me'âlî Abdulmelik b. Abdillâh b. Yûsuf el-Cüveynî, el-Burhân fî uṣ̂uli'l-fikhh, thk. Abdulazîm Mahmûd ed-Dîb. (Misır: Dâru'l-Vefâ, 2012), 1/351.

${ }^{9}$ Basrî, el-Mu 'temed, 2/133; Şîrâzî, Şerhu'l-Luma', 2/631; Cüveynî, et-Telhîs, 2/351 .

10 Şîrâzî, Şerhu'l-Luma', 2/631.

11 Şîrâzî, Şerhu'l-Luma', 2/631; Cüveynî, et-Telhîs, 2/349.

12 Geniş bilgi için bk. Cüveynî, et-Telhîs, 2/424-428.

${ }^{13}$ Bedruddîn Muhammed b. Behâdır ez-Zerkeşî, el-Bahru'l-muhị̂t fí uṣ̂lil'l-fikh (b.y.: Dâru'l-Kutubî, 1414/1994), 6/253.

${ }^{14}$ Ebû Bekr Şemsü'l-eimme Muhammed b. Ebî Sehl Ahmed es-Serahsî, el-Ușûl, thk. Ebü'l-Vefâ el-Efgânî (Beyrut: Dâru'l-Marife, ts.), 1/339; Ebu'l-Abbâs Şihâbuddîn Ahmed b. İdrîs b. Abdirrahmân el-Karâfî, Şerhu Tankîhi'l-fusûl, thk. Tâhâ Abdurraûf Sa'd (b.s.: Şeriketu't-Tibâ'eti'l-Fenniyyeti'l-Muttahide, 1393/1973), 369.

${ }^{15}$ Karâfî, Şerhu Tankîhi'l-fusûl, 369.

${ }^{16}$ Debûsî, Takvîmu'l-edille, 202-203; Muhammed Emîn b. Mahmûd Emîr Pâdişâh el-Buhârî, Teysîru't-Tahrîr, (Misır: Mustafâ elBâbî el-Halebî, 1351/1932) 3/72.

17 Serahsî, el-Ușûl, 1/341.

18 Debûsî, Takvîmu'l-edille, 196, 199; Serahsî, el-Ușûl, 1/364; Karâfî, Şerhu Tankîhi'l-fusûl, 372.

${ }^{19}$ Karâfî, Şerhu Tankîhi'l-fusûl, 371.
} 
kapsamak" anlamlara gelmektedir. ${ }^{20}$ Muzâfün ileh konumunda olan بلا - يبلو isiilin mastar1 olup "sınamak, imtihan etmek, sıkıntı" gibi manalara gelmektedir. ${ }^{21}$

Terim olarak umûmu'l-belvânın tanımı farklı şekillerde yapılmıştır. Tanımların bir kısmı umûmu'l-belvânın etimolojik/lugavî anlamı esas alınarak yapılırken bir kısmı ise olaya taalluk eden hükmün bilinmesi esas alınarak ele alınmakta diğer bir kısmı ise sonucun/neticenin gereği itibariyle ele alınmaktadır.

Umûmu'l-belvânın lugavî anlamı esas alınarak yapılan tanımlardan biri Tûfî́nin "sorumluluğun kendisiyle artığı şey" 22 şeklindeki tanımıdır. Tûfî'nin mezkûr tanımı dikkate alındığında bu haber-i vâhid hususunda söz konusu olan umûmu'l-belvâdan ziyade sorumluluğun artmasından kaynaklanan sıkıntının giderilmesinde muteber olan ve bu konuda önemli bir fonksiyon üstlenen umûmu'l-belvânın tanımı konumunda olduğu görülmektedir. Emîr es-San'ânî (öl. 1182/1768) ise umûmu'l-belvâyı "amel açısından sorumluluğun, mükelleflerin tamamına veya çoğuna şamil olmasıdır" şeklinde tanımlamaktadır. San'ânî'nin bu tanımı her ne kadar ifade açısından Tûfî'nin yaptığı tanımdan farklılık arz etse de mana itibariyle Tûfî'nin yaptığı tanımın bir izdüşümü gibi durmaktadır. Tanımda geçen "amel" kelimesinden maksat şer'î amelî hususlardır. Bununla ilim/zarurî bilgi gerektiren itikâdî hükümler ve ona taalluk eden umûmu'l-belvâ tanım dışında tutulmuştur. Ayrıca tanımda geçen (mükellef) ifadesiyle kast edilen şey, umûmu'l-belvâ kabilinde olan olayların mükelleflere özgü olmalıdır. Zira umûmu'l-belvâ hususunda yapılan araştırmadan maksat, insanların kendisiyle sinanan olay hususunda teklifin sabit olup olmadığı tespit edilmesidir. Bu durum ise sadece mükellefleri ilgilendiren bir husustur.

Umûmu'l-belvânın tanımında olaya taalluk eden hükmün bilinmesini esas alarak tanım yapan âlimlerden biri Ebû Hamîd el-İsferâyînî'dir (öl. 406/1016). İsferâyînî umûmu'l-belvâyı şöyle tanımlamaktadır: "Her bireyin (her mükellefin) bilmesine ihtiyaç duyduğu (şeydir)". ${ }^{23}$ Başka bir ifadeyle umûmu'l-belvâ, her mükellefin kendisiyle amel etmek için varid olan olayın hükmünü bilmesi gerektiği şeydir. ${ }^{24}$

Umûmu'l-belvânın tanımında sonucun/neticenin gereği esas alınarak yapılan tanımlardan biri Muhammed Edîb es-Sâlih'in "herhangi bir konuda varid/sabit olduğu zaman şöhret bulacak ve bilgisi umumileşecek şey" şeklindeki tanımdır. ${ }^{25}$ Mezkûr tanım, haber-i vâhid konusunda varid olan umûmu'l-belvâyı karşılayacak bir tanım olduğu söylenebilir. Haber-i vâhidin umûmu'l-belvâda varid olmaması şartını ileri süren âlimlere göre haber-i vâhid şayet umûmu'l-belvâda vürudu sabit olmuşsa onun bir neticesi olarak haber-i vâhidin hükmü şöhret bulması ve bilgisinin yaygınlaşması gereklidir. Zira umûmu'l-belvâda varid olan haber-i vâhidin hükmünün bilinmesine duyulan ihtiyaçtan dolayı onun bilgisinin yaygınlaşması bir zorunluluktur. ${ }^{26}$

\subsection{Usûlcülerin Hadis Kriteri Olarak Umûmu'l-Belvâya Yaklaşımları}

Usûl âlimleri, umûmu'l-belvâ olarak kabul gören konularda haber-i vâhidin delil değeri mevzusunda farklı görüşler ileri sürmüşlerdir. Usûl âlimlerinin çoğunluğuna göre umûmu'l-belvâ, şer'î amelî meselelerde haber-i vâhidin reddi için bir gerekçe sayılmamaktadır. Onlara göre hadisin senedine halel getirecek herhangi bir etken yoksa zorunlu bilgiyi gerektirmeyen konularda haber-i vâhid ile amel edilir. Dolayısıla onlara göre umûmu'l-belvâ niteliğine sahip olmayan konularda haber-i vâhid ile amel edildiği gibi söz konusu niteliğe sahip olan konularda da haber-i vâhid ile amel

\footnotetext{
${ }^{20}$ Muhammed b. Mükerrem İbn Manzûr, Lisânu'l-'Arab (Beyrut: Dâru İhyâi't-Türâsi'l-'Arabî ve Müessestu't-Târîhi'l-'Arabî, 1996), 9/406; Ahmed Muhtâr Abdulhamîd Ömer, Mu 'cemu'l-Luğati'l- 'Arabiyyeti'l-Mu 'âsıır (Kahire: 'Âlemu'l-Kutub, 1429/2008), 2/1557-1558.

${ }^{21}$ Ebu't-Tâhir Mecduddîn Muhammed b. Yakûb el-Fîrûzâbâdî, el-Kâmûsü'l-muhịt, thk. Komisyon (Beyrut: Müessesetu'r-Risâle, 1426/2005), 1264; Ebu'l-Feyz Muhammed el-Murtazâ b. Muhammed ez-Zebîdî, Tâcu'l- 'arûs min cevâhiri'l-Kâmûs, thk. Komisyon (b.y.: Dâru'l-Hidâye, ts.), 37/206-208.

${ }^{22}$ Ebu'r-Rebî' Necmuddîn Süleymân b. Abdilkavî b. Abdilkerîm et-Tûfî, Şerhu Muhtașari'r-ravża, Abdullah b. Abdulmuhsin etTürkî (Beyrut: Müessesetu'r-Risâle, 1407/1987), 2/233.

${ }^{23}$ Zerkeşî, el-Bahru'l-muhît, 6/558.

${ }^{24}$ Müslim b. Muhammed b. Mâcid ed-Devserî, 'Umûm'l-belvâ dirâsetün nazariyyetün tatbîknyyetün (Riyad: Mektebetü'r-Rüşd, 1420/2000), 48.

25 Bk. Ebu'l-Menâkıb Şihâbuddîn Mahmûd b. Ahmed b. Mahmûd b. Bahtyâr ez-Zencânî, Tahrîcü'l-fürû' 'ale'l-uṣ̂ll. thk. Muhammed Edîb es-Sâlih (Beyrut: Müessesetu'r-Risâle, 1398), 62, tahkik edenin dipnotu.

${ }^{26}$ Konu için bk. Cessâs, el-Fuș̂ul fi'l-uṣûl, 3/107; Debûsî, Takvîmu'l-edille, 199; Serahsî, el-Ușûl, 1/368; Devserî, 'Umûm'l-belvâ, 5152.
} 
edilir. Cumhur kendi görüşünü, haber-i vâhid ile amel etme hususunda varid olan sahabe (r.a.) icmâ'ına dayandırmaktadırlar. Zira sahabe (r.a.) mutlak anlamda haber-i vâhid ile amel etme hususunda icmâ' etmişlerdir. ${ }^{27}$ Ayrıca herkesi ilgilendiren konularda sahabe (r.a.) haber-i vâhid ile amel ettiğine delalet eden bir birçok örnek bulunmaktadır. Bunlardan biri sahabe (r.a.) erkek ve kadının cinsel organlarını birbirine temas etmesi neticesinde guslün gerekli olup olmadığı konusunda ihtilaf ettikleri, bundan dolayı Hz. Aişe'ye (r.a.) haber yolladıkları ve Hz. Aişe'nin “İki cinsel organın birbirine teması gusül gerektir" buyurduğu rivayet edilmiştir. ${ }^{28}$ Söz konusu rivayete göre sahabe herkesi alakadar eden bir konuda kendi görüşlerini bırakıp haber-i vâhid ile amel etmişlerdir. Dolayısıyla bunlara göre herkesi ilgilendiren bir konuda varid olan haberin nakli ile onun bilgisine duyulan ihtiyaç arasında zorunlu bir ilişki bulunmamaktadır. ${ }^{29}$ Başka bir ifadeyle umûmu'l-belvâ niteliğindeki bir konuda varid olan haberin bilgisi ve söz konusu bilgiye dayalı haberin delil değeri ile hadisin râvi yoğunluğuna göre en az meşhûr derecesine varması arasında zorunlu bir bağ yoktur. Cumhur söz konusu meselede haber-i vâhid ile amel edileceği hususunun ispatı için ayrıca şu gerekçeyi de öne sürmüşlerdir: Herkesi ilgilendiren bir konuda kıyas, delil olarak kabul görmektedir. Kıyasın delil olarak kabul gördüğü bir konuda haber-i vâhidin evleviyetle kabul görmesi gerekir. Zira kıyas fer' haber-i vâhid ise asıldır. Aslın delil değeri her zaman fer 'den daha üstündür. ${ }^{30}$

Hanefî âlimlerin büyük çoğunluğu, Mutezileden Ebû Abdillâh el-Basrî (öl. 369/979) ve Mâlikî âlimlerden İbn Huveyzmendâd'a (öl. 390/1000) ${ }^{31}$ göre umûmu'l-belvâ niteliğindeki bir meselede varid olan haber-i vâhid ile amel edilmez. ${ }^{32}$ Onlara göre söz konusu meselede varid olan haber-i vâhid

\footnotetext{
${ }^{27}$ Ebu'l-Hüseyn el-Basrî, el-Mu 'temed, 2/168; Ebû Ya'lâ el-Ferrâ', el-'Udde fî uṣ̂lli'l-fiḳh, 3/885; Ebû İshâk İbrâhîm b. Alî b. Yûsuf el-Fîrûzâbâdî eş-Şîrâzî, et-Tebṣıra fì ușûli'l-fiḳh, thk, Muhammed Hasan Heyto (Dımaşk: Dâru'l-Fikir, 1400/1980), 314; Ebü'1Muzaffer Mansûr b. Muhammed b. Abdilcebbâr et-Temîmî el-Mervezî es-Sem'ânî, Kavâți 'u'l-edille fi'l-uṣ̂ul, thk. Muhammed Hasan İsmâîl eş-Şâfiî (Beyrut: Dâru'l-Kutubi'l-'İlmiyye, 1418/1999), 1/355; İmâmü'l-Haremeyn Ebu'l-Me'âlî Abdulmelik b. Abdillâh b. Yûsuf el-Cüveynî, el-Burhân fi ușûli'l-fikhh, thk. Abdulazîm ed-Dîb (Misır: Dâru'l-Vefâ, 2012), 1/378-379; Hüccetü'lİslâm Ebû Hâmid Muhammed b. Muhammed b. Muhammed b. Ahmed et-Tûsî el-Gazzâlî, el-Mustasfâ fì 'ilmi'l-ușûl, thk. Muhammed Abdusselâm Abduşşâfî (Beyrut: Dâru'l-Kutubi'l-'İlmiyye, 1413/1993), 136; Ebû Abdillâh Fahruddîn Muhammed b. Ömer b. Hüseyn er-Râzî, el-Mahșûl fî 'ilmi'l-ușûli'l-fikhh, thk. Tâhâ Câbir el-'Alvânî, (Beyrut: Müessesetu'r-Risâle, 1418/1998), 4/441; Safiyyuddîn Muhammed b. Abdurrahmân el-Hindî el-Urmevî, Nihâyetu'l-vuṣûl fi dirâyeti'l-uṣ̂ll, thk. Sâlih b. Süleymân Saîd b. Sâlim es-Süveyh (Mekke: el-Mektebetu't-Ticâriyye, 1416/1996), 7/2960-2962 .

${ }^{28}$ Ebû Abdillâh Mâlik b. Enes b. Mâlik b. Ebî Âmir el-Asbahî İmam Mâlik, el-Muvatța', nşr. Muhammed Fuâd Abdulbâkî (Beyrut: Dâru İhyâi't-Türâsi'l-'Arabî, 1406/1985) "Tahâret", 73; Ebû Abdullâh Muhammed b. İdrîs eş-Şâfî̂, el-Müsned (Müsnedu'ş-Şâfi î̀), thk. Mâhir Yâsîn Fahl (Kuveyt: Şeriketu Ğirâs li'n-Neşri ve't-Tavzî‘, 1425/2004), 1/196 (No. 95).

${ }^{29}$ Ahmet Aydın, "Bir Hadis Tenkid Kriteri Olarak Umûmü'l-Belvâ Kavramı", Kilis 7 Aralık Üniversitesi İlahiyat Fakültesi Dergisi 5/9 (Aralık 2018), 372.

${ }^{30}$ Alâuddîn Abdulazîz b. Ahmed b. Muhammed. Alâuddîn Abdulazîz b. Ahmed b. Muhammed el-Buhârî, Keşfü'l-esrâr fî şerhi Ușûli'l-Pezdevî, (b.y.: Dâru'l-Kitâbi'l-İslâmî, ts.), 3/17; Zerkeşî, el-Bahru'l-muhị̂t, 6/257.

${ }^{31}$ Biyografi kitaplarında İbn Huveyzmendâd'ın künye ve nesebi hususunda farklılık olsa da genel kabule göre onun künyesi, isimi ve nesebi "Ebû Bekr (Ebû Abdillah) Muhammed b. Ahmed b. Alî b. İshâk b. Huveyzmendâd" şeklindedir. İbn Huveyzmendâd Mâlikî mezhebin önemli âlimlerinden biri olup bazı fikhi meselelerde ve haber-i vâhidin bilgi değeri ve umûmu'l-belvâya dair konularda varid olan haber-i vâhid ile amel edilemeyeceği gibi konularda Mâlikî mezhebine aykırı görüş beyanında bulunduğu için eleştirilere maruz kalan bir âlimdir. Tabakât eserlerinde İbn Huveyzmendâd'ın doğum tarihi ile ilgili herhangi bir bilgi bulunmamakta söz konusu eserlerde onun 390'da vefat ettiği belirtilmektedir. Bk. Şemsuddîn Ebu'l-Me'âlî Muhammed b. Abdirrahmân b. el-Ğazzî, Divânu'l-i̇slâm, thk. Seyyid Kesrevî Hasan (Beyrut: Dâru'l-Kutubi'l-'illmiyye, 1411/1990), 2/243.

32 Hanefî âlimlerin büyük çoğunluğuna göre ister farz ve haram gibi herkesin yamakla veya yapmamakla mükellef olduğu bir konuyla alakalı olsun isterse sünnet olan meselelerle alakalı olsun mutlak anlamda umûmu'l-belvâ niteliğindeki bir meselede varid olan haber-i vâhid ile amel edilmez. Cessâs, Kemâluddîn İbnü'l-Hümâm, İbn Emîru Hâc, Emîr Pâdişâh gibi bazı âlimlere göre ise vucûb ve tahrîm niteliğini taşıyan ve herkesi alakadar eden konularda varid olan haber-i vâhid ile amel edilmez; buna mukabil sünnet niteliğini haiz olan konularda haber-i vâhid umûmu'l-belvâda dahi varid olsa kendisiyle amel edilir. Cessâs, elFușûl fi'l-uṣ̂ll, 3/214-215; el- Debûsî, Takvîmu'l-edille, 199; Ebû Ya'lâ el-Ferrâ', el- 'Udde, 3/885; Ebû'l-Velîd Süleyman b. Halef elBâcî, İhkâmu'l-fusûl fî ahkâmi'l-usûl, thk. Abdulmecid et-Türkî (Dâru'l-Ğarbi'l-İslâmî, 1415/1995), 1/350; Şîrâzî, et-Tebṣıra, 314; Serahsî, el-Ușûl, 1/369; Sem'ânî, Kavâti 'u'l-edille, 1/355-356; Cüveynî, el-Burhân, 1/378-379; Gazzâlî, el-Mustașfâ, 136; Ebü'1-Hattâb Mahfûz b. Ahmed b. el-Hasen el-Kelvezânî, et-Temhîd fî ușûli'l-fiḳh, thk. Mufîd Muhammed Ebû Amşe - Muhammed b. Alî b. İbrâhîm (Câmi‘atu Ümmü'l-Kura: Merkezu Bahsi'l-İlmiyyi ve İhyâi't-Turâsi'l-İ̇lâmî, 1406/1985), 3/86-87; Âmidî, el-İhkâm, 2/112; Ebu'l-Abbâs Muzaferuddîn b. Alî İbnu's-Sââtî, Bedî'u'n-Nizâm (Nihâyetu'l-vușûl ilâ 'ilmi'l-uṣ̂ul), thk. Sa'd b. Mehdî es-Sülemî (Mekke: Câmi‘atu Ummu'l-Kurâ, 1405/1985), 1/366-367; Abdulazîz el-Buhârî, Keşfü'l-esrâr, 3/16-17; Zerkeşî, el-Bahru'l-muhị̂t, 6/257; Ebû Abdillâh Hasan b. Alî b. Talha er-Recrâcî eş-Şûşâvî, Refu'n-nikâb an Tenkîhi'ş-Şihâb, thk. Ahmed b. Muhammed esSerrah - Abdurrahman b. Abdillah ec-Cibrîn (Riyad: Mektebetu'r-Ruşd, 1425/2004), 5/174; Ebû Abdillâh Şemsuddîn
} 
manevî inkitâ niteliğindedir. ${ }^{33}$ Herkesin bilgisine ihtiyaç duyduğu bir hususta manevî inkitâ niteliğini taşıyan haberin bir delil değeri yoktur. Onlar, herkesin kendisiyle mükellef olacak ve onları ilgilendirecek bir konuda Peygamber'in (s.a.v.) az sayıdaki insanları bilgilendirmesi ve diğerlerini bundan mahrum bırakmasının mümkün olmadığını söylemişlerdir. Zira Peygamber (s.a.v.), insanların bilgisine muhtaç oldukları konularda onları aydınlatmakla görevlendirilmiş ve sahabe de Peygamber (s.a.v.) tarafından kendilerinden sonra gelen insanları aydınlatmakla görevlendirilmişlerdir. ${ }^{34} \mathrm{Bu}$ âlimlere göre herkesi ilgilendiren ve herkesin bilgisine ve hükmüne muhtaç olduğu konuların bilgisi ve hükmü, mutlaka Peygamber (s.a.v.) tarafından beyan edilmiş ve sahabe de -râvi yoğunluğu açısında- en az müstefîd/meşhûr sayısınca onu nakletmiştir. Şayet umûmu'l-belvâya dair konularda varid olan haber-i vâhidin nakli, râvi yoğunluğu meşhûr râvi sayısına ulaşmamış ise söz konusu haber ya mensûhtur ya da râvi bu hususta yanılmıştır. ${ }^{35}$ Cumhurun aksine bu âlimlere göre herkesi ilgilendiren bir konuda varid olan haberin nakli ile onun bilgisine duyulan ihtiyaç arasında zorunlu bir ilişki bulunmaktadır. Dolayısıyla herkesin bilgisine ihtiyaç duyduğu haber, ilk nesilden itibaren râvi yoğunluğu açısından en az şöhret derecesine ulaşması zorunludur.

Hanefî usûl eserlerinin bir kısmında umûmu'l-belvâ niteliğindeki konularda varid olan haber-i vâhidin delil değerinin olmadığı düşüncesi bütün Hanefî âlimlere isnad edilmektedir. Örneğin İbn Hümâm (öl. 861/1457) umûmu'l-belvâda varid olan haber-i vâhid konusunu ele alırken çokça tekerrür eden ve herkesin kendisine ihtiyaç duyduğu bir konuda şöhret bulmayan ve ümmet tarafından kabul görmeyen haber-i vâhid ile bir vâcibin sabit olmayacağını ve bunun Hanefîlerin tamamının görüşü olduğunu belirtir. ${ }^{36}$ Ancak böyle bir iddiayı tüm Hanefî âlimlere teşmil etmek gerçeği yansitmamaktadır. Muhtemelen İbn Hümâm, mezkûr ifadeyle mezhebin bu konudaki genel temayülünü kastetmektedir. Yapılan araştırmada tespit edildiği kadarıyla Hanefî usûlcülerden ilk olarak herkesi ilgilendiren ve herkesin bilgisine ihtiyaç duyduğu bir konuda varid olan haber-i vâhid ile amel edilemeyeceği düşüncesi İsâ b. Ebân'a (öl. 221/836) aittir. ${ }^{37}$ İsâ b. Ebân'dan önceki Hanefî âlimlerden bu hususla ilgili herhangi bir şey nakledilmemiştir. Örneğin Cessâs (öl. 370/981) haber-i vâhidin kendisiyle reddedilen illetleri/nedenleri ele alırken İsâ b. Ebân'dan nakilde bulunarak söz konusu illetlerin arasında umûmu'l-belvâyı saymaktadır. ${ }^{38}$ Hanefî usûlcülerden Debûsî (öl. 430/1039) ise haber-i vâhidin tenkîdi meselesini işlerken haber-i vâhidin hadiseye/olaya arz edileceğini, şayet hadise herkesi ilgilendiren bir husus ise söz konusu haber şaz ve asılsız olarak değerlendireceğini belirtir. ${ }^{39}$ Pezdevî ve Serahsî (öl. 483/1090) de Debûsî'nin ifadelerine yakın sözleri kullanmakta ve umûmu'l-belvânın haber-i vâhid için reddetme gerekçesi olduğunu ifade etmektedirler. ${ }^{40}$ Debûsî, Pezdevî ve Serahsî mezkûr konuyu ele alırken mutekaddim Hanefî âlimlerden herhangi birine atıfta bulunmadıkları görülmektedir. Onların başta Ebû Hanife olmak üzere mezhebin üç büyük imama atıfta bulunmamaları bu düşüncenin onlardan sonra ortaya çıktığının bir göstergesi olduğunu söylemek mümkündür. Hanefî âlimlerinden Abdulazîz el-Buhârî (öl. 730/1330) ise mezkûr düşünceyi Kerhî ö. 340/952) ve muteahhir Hanefî âlimlere nispet etmektedir. ${ }^{41}$ Ancak onun mevzubahis düşünceyi mutekaddim âlimlerden Kerhî’ye nispet etmesi bu meselenin Hanefî usûl eserlerinde Kerhî ile daha yaygınlık kazanması sebebiyle olabilir. Zira daha önce işaret edildiği gibi umûmu'l-belvâ niteliğini taşıyan bir konuda varid olan haber-i vâhid ile amel edilemeyeceği düşüncesi İsâ b. Ebân'a aidiyeti Cessâs tarafından ortaya konulmuştur.

Hanefî mezhebi dışındaki diğer mezheplere müntesip bazı usul âlimleri umûmu'l-belvâ vasfına sahip konularda varid olan haber-i vâhid ile istidlâl edilemeyeceği düşüncesini daha erken bir

\footnotetext{
Muhammed b. Muhammed b. Muhammed el-Halebî İbn Emîru Hâc, et-Takrîr ve't-tahbîr (Beyrut: Dâru'l-Kutubi'l-'İlmiyye, 1403/1983), 2/296; Emîr Pâdişâh, Teysîru't-Tahrîr, 3/112.

33 Pezdevî, Kenzü'l-vüsûul, 177; H. Yunus Apaydın, "Haber-i Vâhid”, Türkiye Diyanet Vakfı İslâm Ansiklopedisi (İstanbul: TDV Yayınları, 1996) 14/360.

34 Serahsî, el-Ușûl, 1/369.

${ }^{35}$ Debûsî, Takvîmu'l-edille, 199; Serahsî, el-Ușûl, 1/369; Sem'ânî, Kavâtị 'u'l-edille, 1/355-356.

36 İbn Emîru Hâc, et-Takrî̀r ve't-tahbîr, 2/295.

${ }^{37}$ Metin Yiğit, İlk Dönem Hanefi Kaynaklara Göre Ebû Hanîfénin Usûl Anlayışında Sünnet (İstanbul: İz Yayıncılık, 2009$), 298$.

${ }^{38}$ Cessâs, el-Fușûl fi'l-ușûl, 3/113.

${ }^{39}$ Debûsî, Takvîmu'l-edille, 196.

40 Pezdevî, Kenzü'l-vüșûl, 177; Serahsî, el-Ușûl, 1/369.

${ }^{41}$ Abdulazîz el-Buhârî, Keşfü'l-esrâr,
} 
döneme kadar götürmektedirler. Bazı usûlcüler mezkûr düşüncenin çıkışını Ebû Hanife'ye (öl. 150/767) dayandırmaktadırlar. İbn Hazm (öl. 456/1064), Gazzâlî (öl. 505/1111) Ebû Bekr İbnu'l-Arabî (öl. 543/1148), Zencânî (öl. 656/1258 söz konusu düşüncenin çıkışını Ebû Hanife'ye dayandıran âlimlerdendirler. ${ }^{42}$ İbn Hazm, Ebû Hanife'nin râvinin rivayet ettiği habere muhalefet etmemesi (haberin aksiyle amel etmemesi), umûmu'l-belvâya dair konularda varid olmaması ve kıyas ile çelişmemesi gibi haber-i vâhidin kabulü için birtakım şartlar ileri sürdüğünü ve ileri sürdüğu şartlar ile ehli hadise muhalefet ettiğini iddia etmektedir. ${ }^{43}$

Muhammed ed-Desûkî, umûmu'l-belvâda varid olan haber-i vâhid ile istişhâd edilemeyeceği fikrinin Muhammed b. Hasan eş-Şeybânî’ye (öl. 189/805) dayandırmaktadır. Ona göre İmam Muhammed söz konusu meseleyi açıkça ifade etmese de ancak "messu'z-zeker" meselesinde olduğu gibi aslında bu kuralı uygulamaktadır. ${ }^{44}$ Ancak mesele iyi şekilde tetkik edildiğinde İmam Muhammed'in konuyla ilgili hadislerle amel etmemesinin nedeni aksi şekilde varid olan hadis ve eserlerdir. Zira o, Ebû Hanife'nin tenasül uzvuna dokunmanın abdesti bozup bozmayacağ hususundaki görüşünü savunurken konuyla ilgili başka hadislere ve sahabe görüşlerine dayanarak karşıt hadisi reddetmektedir. ${ }^{45}$

Ebu'l-Hüseyn el-Basrî, Cüveynî (öl. 478/1085), Mâzerî (öl. 536/1141) ve Âmidî gibi bazı âlimler, umûmu'l-belvâ vasfına sahip konularda varid olan haber-i vâhid ile amel edilemeyeceği fikrini Ebu'lHüseyn el-Kerhî'ye atfetmektedirler. ${ }^{46}$ Cüveynî, mutekaddim âlimlerin umûmu'l-belvâ niteliğini taşıyan konularda varid olan haber-i vâhid ile amel ettiklerini ancak Kerhî ve muteahhir Hanefî âlimlerinden bazılarının söz konusu meselede haber-i vâhid ile amel etmediklerini vurgulamaktadır. ${ }^{47}$ Yukarıda da ifade edildiği gibi Gazzâlî el-Menhûl adlı eserinde söz konusu düşünceyi Ebû Hanife'ye isnad ederken daha sonra kaleme aldığ̣ el-Mustasfâ adlı eserinde ise mevzubahis görüşü Kerhî ve eshâbu'r-rey olarak nitelenen bazı Hanefî âlimlere isnad etmektedir. ${ }^{48}$

Ebû Ya'lâ el-Ferrâ (öl. 458/1066), Ebû İshâk eş-Şînâzî (öl. 476/1083), Ebu'l-Vefâ İbn Akîl (513/1119) gibi bazı âlimler ise umûmu'l-belvâ niteliği taşıyan konularda varid olan haber-i vâhid ile amel edilemeyeceği görüşünü "eshâbu Ebî Hanife" gibi daha genel bir ifade kullanarak mutlak şekilde Hanefî mezhebine müntesip âlimlere atfetmektedirler. ${ }^{49} \mathrm{Bu}$ âlimlerin ifadelerinden de anlaşılan söz konusu tartışmanın Ebû Hanife'den sonra meydana geldiğidir. Zira Ebû Hanife'nin böyle bir görüşünün olması durumunda "eshâbu Ebî Hanife" yerine "Ebû Hanife ve eshâbuhu" şeklinde bir ifade kullanılırdir.

\section{Hanefilerin Umûmu'l-Belvâya İlişkin Gerekçelerine Cumhurun Tenkîtleri}

Yukarıda da ifade edildiği gibi Hanefî usûlcülerin yanı sıra Ebû Abdillâh el-Basrî, İbn Huveyzmendâd gibi âlimler, haber-i vâhidin kabulü için ileri sürülen ve herkes tarafından kabul görülen şartlara ilaveten birtakım şartlar ileri sürmüşlerdir. Bu şartlardan biri de haber-i vâhidin herkesin kendisine ihtiyaç duyduğu ve bilmesi gerektiği konularla ilgili olmamasıdır. Bu âlimler, söz konusu şartın gerekliliği için birçok gerekçeyi öne sürmüşlerdir. Mezkûr şartı kabul etmeyen âlimler

\footnotetext{
42 Ebû Hâmid Muhammed b. Muhammed b. Muhammed b. Ahmed et-Tûsî el-Gazzâlî, el-Menhûul min ta 'lîkâti'l-ușûl, thk. Muhammed Hasan Heyto (Beyrut: Dâru'l-Fikr el-Mu'âsır, 1419/1998), 378; Ebû Bekr Muhammed b. Abdillâh b. Muhammed İbnu'l-Arabî el-Meâfirî, el-Mahṣ̂ul fî̀ uṣ̂uli'l-fikh, thk. Hüseyn Alî - Saîd Fûde (Uman: Dâru'l-Beyârik, 1420/1999), 117; Zencânî, Tahrîcü'l-fürû' 'ale'l-ușûl, 63-64.

${ }^{43}$ Ebû Muhammed Alî b. Ahmed b. Saîd b. Hazm el-Endelüsî el-Kurtubî, el- 'Irâb 'ani'l- hîreti ve'l-iltibâs el-mevcûdeyn fì mezâhibi ehli'r-rey ve'l-kiyâs, thk. Muhammed b. Zeynilâbidîn Rüstem (Riyad: Dâru'l-Edvâi's-Selef, 1425/2005), 1/123. Ayrıca bk. Aydın, "Bir Hadis Tenkid Kriteri Olarak Umûmü'l-Belvâ Kavramı", 367.

${ }^{44}$ Muhammed ed-Desûkî, el-İmam Muhammed b. el-Hasan eş-Şeybânî ve eseruhu fi'l-fikh (Davha: Daru's-Sekafe, 1407/1987), 212213.

45 Örnek için bk. Ebû Abdillâh Muhammed b. el-Hasen eş-Şeybânî, Muvațta'ü'l-İmâm Mâlik rivâyetü Muhammed, thk. Abdulvahhâb Abdullatif (b.y.: el-Mektebetu'l-İlmiyye ts.) 35; Ebû Abdillâh Muhammed b. el-Hasen eş-Şeybânî, el-Hucce 'alâ ehli'l-Medîne, thk. Mehdî Hasan el-Kîlânî el-Kâdirî (Beyrut: 'Âlemu'l-Kutub, 1403), 1/59.

${ }^{46}$ Ebu'l-Hüseyn el-Basrî, el-Mu 'temed, 2/168; Cüveynî, et-Telhîs, 2/431; Ebû Abdillâh Muhammed b. Alî b. Ömer et-Temîmî elMâzerî, Îdâhu'l-mahșûl min Burhâni'l-uṣ̂ul, thk. Ammâr et-Tâlibî (Tunus: Dâru'l-Garbi'l-İslâmî, 1421/2001), 524; Âmidî, el-ịhkâm, $2 / 112$.

47 Cüveynî, et-Telhîs, 2/431.

${ }^{48}$ Gazzâlî, el-Mustașâ, 135.

${ }^{49}$ Ebû Ya'lâ el-Ferrâ', el-'Udde, 3/885; Ebû İshâk İbrâhîm b. Alî b. Yûsuf el-Fîrûzâbâdî eş-Şîrâzî, el-Luma 'fi usûli'l-fikh. thk. Alî Abdulazîz (Kuveyt: Cem 'iyetu İhyâi't-Turâsi'l-İslâmî, 1407/1987), 73; İbn Akîl, el-Vâdıh, 2/140;
} 
ise getirilen gerekçelerin onlar için bir delil teşkil edemeyeceğini iddia etmişlerdir. Burada umûmu'lbelvâ şartını ileri süren âlimlerin bazı gerekçeleri ve bu gerekçelere verilen cevaplar ele alınacaktır.

1. Haber-i vâhidin kabul edilebilmesi için onun umûmu'l-belvâya dair konularda varid olmama şartını ileri süren âlimler, naklî delillerle istidlalde bulundukları gibi aklî delillerle de istidlalde bulunmuşlardır. Yukarıda da zikredildiği gibi aklî olarak şu gerekçeyi ileri sürmüşlerdir: Peygamber (s.a.v.) herkesin bilmesi gerektiği ve kendisiyle mükellef olduğu bir meselenin hükmünü az sayıdaki insanlara bildirmesi ve diğerlerini bundan mahrum bırakması mümkün değildir. Zira Peygamber (s.a.v.) bu tür konularda herkesi aydınlatmakla görevlendirilmiş ve sahabe de Peygamber (s.a.v.) tarafından kendilerinden sonraki nesilleri aydınlatmakla görevlendirilmişlerdir. Dolayısıyla vucûb ve tahrîm gibi herkesi ilgilendiren ve herkesin bilmesi gereken hükümlerin en az müstefîz/meşhûr râvi sayısınca rivayet edilmesi kaçınılmazdır. Şayet herkesi ilgilendiren konuların hükmü râvi sayısı açısından müstefîz/meşhûr seviyesinde nakledilmemiş ise söz konusu rivayet ya mensûhtur ya da sahih değildir. ${ }^{50}$ Cessâs vucûb ve tahrîm gibi şer î̀ hükümleri ihtiva eden haberlerin topluluk tarafından değil de fertler tarafından rivayet edilmesinin caiz olmadığını belirtir. ${ }^{51}$

Cumhur, Hanefî âlimlerin mezkûr gerekçelerine şu şekilde cevap vermişlerdir: Bir emîrin pazarda öldürülmesi, güneşin tutulması, zelzele gibi âdeten yaygınlık kazanmaması mümkün olmayan durumlarda haber-i vâhid kabul görmez. Zira bu tür olaylar, vuku bulduğu andan itibaren yaygınlık kazanan türdendir. Kur'ân da bu kabildendir. Yani Kur'ân ayetlerinin naklinde de haber-i vâhid kabul edilmez. Zira Peygamber (s.a.v.) Kur'ân'ı Kerîm'i yaymakla mükellef olup herkesi bu hususta bilgilendirir ve herkese duyurmaya özen gösterirdi. Allah (c.c), Peygamber'i (s.a.v.) namaz ve oruç gibi İslam'ın esasları yaymakla da mükellef kılmış ve Peygamber (s.a.v.) de İslam'ın esasları niteliğindeki hükümleri yaymaya itina göstermiştir. Bunun yanı sıra nikâh, alışveriş gibi zarurî olmayan muamelata dair esasları yaymış ve tevatür düzeyinde nakledilmiştir. Bununla birlikte Allah (c.c.) -cinsel organa dokunmanın abdesti bozacağı meselesinde olduğu gibi- İslam'ın esaslarının tafsilatıyla ilgili hususlarda Peygamber'e (s.a.v.) insanları haber-i vâhide havale etmesine cevaz vermiştir. ${ }^{52}$

Cumhûr, Peygamber'in (s.a.v.) umûmu'l-belvâ niteliği taşısa dahi hadisenin hükmünü tevatür veya müstefîd sayısınca kişilere bildirmekle mükellef olmadığını ifade etmektedirler. Onlar Peygamber'in (s.a.v.) sadece tebliğ etmekle mükellef olduğunu, tebliğ ise haberin/hükmün birden fazla kişiye bildirilmekle hâsıl olabileceği gibi tek bir kişiye bildirilmekle de hâsıl olacağını iddia etmektedirler. Cumhura göre hadisenin hükmünün haberi kendisine ulaşan kişilerin söz konusu haber ile amel etmeleri zorunlu iken, haberin kendilerine ulaşmayan kişiler ise içtihatla ve haberi talep etmekle mükelleftirler..$^{53}$ Onlar umûmu'l-belvâya dair konularda olsun veya olmasın Allah (c.c.) haber-i vâhid vasıtasıyla insanları kendisine ibadet ettirmesi ve onları ibadet ile mükellef tutmasının aklen mümkün olduğunu bu hususta aklî ve naklî bir mânianın da olmadığını belirtmektedirler. ${ }^{54}$

Cumhur, umûmu'l-belvâya dair konularda kıyasın kaynak olarak kabul gördüğünü; birçok konuda fer", hükmü haber-i vâhid ile sabit olan asla kıyas edildiğini söyleyerek mezkûr konuda asıl konumunda olan haber-i vâhid ile amel etmenin kıyasa göre daha evla olduğunu ifade etmişlerdir. ${ }^{55}$ Bu bağlamda cumhura göre haber-i vâhid zan ifade etse de umûmu'l-belvâ niteliğgindeki bir olayın hükmünü birçok kişiye değil de -râvi yoğunluğu açısından- müstefîd derecesine ulaşmayacak kadar kişilere haber vermekle iktifa etmek caizdir. Dolayısıyla onlara göre Peygamber (s.a.v.) umûmu'1belvâ niteliğindeki bir olayın hükmünü birçok kişiye bildirmekle mükellef değildir. ${ }^{56}$

\footnotetext{
50 Cessâs, el-Fuṣ̂l fi'l-ușûl, 3/114-115; Ebû Ya'lâ el-Ferrâ', el- 'Udde, 3/881; Debûsî, Takvîmu'l-edille, 199; Serahsî, el-Ușûl, 1/369; Ebû Bekr Alâüddîn Muhammed b. Ahmed es-Semerkandî, Mîzânu'l-uṣ̂ul fì netâ 'ici'l- 'ukûul, thk. Muhammed Zekî Abdulberr (Katar: Metâbi ‘u'd-Devha el-Hadîse, 1404/1984), 434; Ebu'l-Feth Alâuddîn Muhammed b. Abdilhamîd el-Üsmendî, Beżlü'n-nazar fi'l-uṣ̂ul, Muhammed Zekî Abdulberr (Kahire: Mektebetu't-Turas, 1412/1992), 474.

${ }^{51}$ Cessâs, el-Fuṣ̂ul fi'l-uṣ̂ul, 3/115.

52 Gazzâlî, el-Mustasfâ, 135-136; Râzî, el-Mahṣûl, 4/440;

${ }^{53}$ Ebû Ya'lâ el-Ferrâ', el- 'Udde, 3/885; Muvaffakuddîn Abdullah İbn Kudâme, Ravżatü'n-nâzıı ve cünnetü'l-münâzır fì uṣ̂uli'l-fikh 'alâ mezhebi'l-İmâm Ahmed (b.y.: Müessesetu'r-Reyyân li't-Tibâ‘ ve'n-Neşr ve't-Tevzî́, 1423/2002), 1/369.

${ }^{54}$ Alî b. İsmâîl es-Sanhâcî el-Ebyârî, et-Tahkị̂k ve'l-beyân fi şerhi'l-Burhân fi uṣûli'l-fikhh, thk. Alî b. Abdurrahmân Bessâm el-Cezâirî (Kuveyt: Dâru'd-Diyâ, 1434/2013), 2/768.

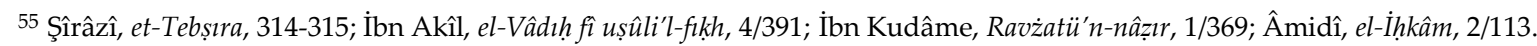

${ }^{56}$ Gazzâlî, el-Mustaşâ, 136; İbn Kudâme, Ravżatü'n-nâzıır, 1/369-370.
} 
Umûmu'l-belvâya dair tartışmalarda cumhurun görüşünün benimseyen Gazzâlî, Allah (c.c.) -faiz konusunda olduğu gibi- Peygamber'e (s.a.v.) insanları kıyasa havale etmesine izin verdiği gibi bazı hükümlerde onları haber-i vâhide havale etmesine de izin verdiğini belirtir. Gazzâlî̀ye göre Peygamber (s.a.v.), kolay bir şekilde "yiyecek maddeleri yiyecek maddeler, ölçülebilir maddeleri de ölçülebilir maddeler mukabilinde satmayın" diye bileceği halde onu söylemekle mükellef tutulmadığ1 gibi umûmu'l-belvâ niteliğindeki bazı olayların hükmünü genele bildirmekle de mükellef tutulmamıştır. Gazzâlî, umûmu'l-belvâya dair olayların hükmünün ispatının haber-i vâhide dayanmasında birtakım maslahatların olabileceğini, dolayısıyla râvinin doğru söylemesinin mümkün olduğunu ve tasdik edilmesi gerektiğini beyan etmektedir. ${ }^{57}$

Cumhur, diğer konularda olduğu gibi umûmu'l-belvâ niteliğindeki konularda varid olan haber-i vahidin râvisi sika, adil, naklettiği haberde doğruluğu mümkün ve rivayet ettiği haber hususunda emin bir râvi ise söz konusu nitelikler, zann-i galip ile onun doğruluğuna delâlet edeceğini söylemektedirler. Cumhura göre diğer haberlerde olduğu gibi umûmu'l-belvâ konularında da mezkûr sıfatlara sahip olan râvinin tasdik edilmesi gereklidir. ${ }^{58}$

Cumhûr, ayrıca umûmu'l-belvâ niteliğine sahip olan konularda haber-i vâhidi kabul etmeyen âlimlerin de bizatihi umûmu'l-belvâya dair bazı konularda haber-i vâhid ile istişhâtta bulunduklarını ileri sürerek onların iddialarına cevap vermişlerdir. Cumhur, bu hususta onlara telâzüm yöntemiyle şu şekilde cevap vermişlerdir: Haber-i vâhidin umûmu'l-belvâda varid olmama şartını koşanların kendileri vitir, hacamat, fasd ve namazda kahkahanın hükmü, ölü yıkayan kişiye guslün vâcibliği, kamettin çiftli oluşu gibi meselelerdeki iddialarını haber-i vâhide dayandırmaktadırlar. Bu husus mezkûr konuların tamamının umûmu'l-belvâ niteliğinde olmasından ötürü onların söz konusu iddialarını boşa çıkarmaktadır. ${ }^{59}$

2. Umûmu'l-belvâya ilişkin hususlarda varid olan haber-i vâhid ile amel edilemeyeceğini iddia eden âlimler, herkesi ilgilendiren bir olayın hükmünün yaygınlık kazanmaması, bu hükmü fark etmeyenlerin ibadetlerinin ifsadına neden olacağını iddia etmektedirler. ${ }^{60}$

Cumhur, bu âlimlerin öne sürdükleri gerekçenin müsellem olmadığını söyleyerek şöyle cevap vermektedir: İnsanlar hükümlerin haberi kendilerine ulaşmadan ve onun bilgisine vakıf olmadan hükümlere riayet etmekle sorumlu olmayacaklar ve onların gereğini yerine getirmedikleri için de cezayı hak etmeyecekler; ancak insanlar, hükümlerin bilgisi kendilerine ulaştıktan sonra söz konusu hükümlere riayet etmekle mükellef olacaklarıdır. ${ }^{61}$

3. Yukarıda da geçtiği gibi umûmu'l-belvâ niteliği taşıyan hususlarda varid olan haber-i vâhid ile amel edilemeyeceğini söyleyen âlimlerin ileri sürdükleri aklî gerekçelerden biri de şudur: Herkesi ilgilendiren hususlarda çok soru sorulur, çok soru sorulunca cevabı da çok olur, cevap çok olunca âdeten cevabı aktaran râvilerin sayısı da artar. Bu tür durumlarda haber, insanların çoğu tarafından değil de sadece haber-i vâhid yoğunluğunda aktarılması bu haberin ya asılsız veya râvinin sehvinden kaynaklandığının bir göstergesidir. Dolayısıyla asılsız veya sehven nakledilen haberle amel edilemez. ${ }^{62}$

Cumhur bu iddiaya da şu şekilde cevap vermektedir: Haberin geneli ilgilendirmesi ve cevabın fazla oluşu ile onun genel tarafından nakledilmesi arasında zorunlu bir bağ bulunmamaktadır. Bazen soruya verilen cevap çok olduğu halde naklin az oluşunun caiz olduğunu, zira haberin nedenlere ve ihtiyaçlara göre nakledileceğini ve birçok sahabenin haberlere/hadislere vakıf oldukları halde onları rivayet etmediklerini görülmektedir. Cumhur, zikrettikleri iddialarını bazı örneklerle temellendirmiştir. Getirilen örneklerden biri de şudur: Peygamber (s.a.v.) çok sayıda sahabeyle hac yaptığı ve hacın menâsikini genel şekilde beyan ettiği halde az sayıda sahabe tarafından rivayet

\footnotetext{
57 Gazzâlî, el-Mustasfâ, 136.

58 Âmidî, el-ịhkâm, 2/113.

${ }^{59}$ Gazzâlî, el-Mustașfâ, 135-136; Râzî, el-Mahṣ̂ul, 4/442; İbn Kudâme, Ravżatü'n-nâżır, 1/369; Âmidî, el-ịhkâm, 2/112.

60 Âmidî, el-ịhkâm, 2/113; Devserî, 'Umûm'l-belvâ, 205.

61 Gazzâlî, el-Mustașfâ, 136; Âmidî, el-İhkâm, 2/113.

${ }^{62}$ Ebûbekir Ahmed b. Ali b. Sabit Hatip el-Bağdâdî, el-Fakîh ve'l-mütefakkihh, thk. Ebû Abdirrahmân Âdil b. Yûsuf el-Garâzî, (Suudi Arabistan: Dâru İbni'l-Cevzî, 1421), 1/362; Şîrâzî, et-Tebṣıra, 315; İbn Akîl, el-Vâdıh fì uṣ̂uli'l-fikhh, 4/391-392; Üsmendî, Beżlü'n-nazar, 474; Buhârî, Keş̧ü'l-esrâr, 3/17.
} 
edilmiştir. ${ }^{63}$ Söz konusu hadisten de anlaşılan haberin geneli ilgilendirmesi ile onun nakli arasında bir bağ bulunmamaktadır. "Ameller niyete göredir" hadisi de buna örnek olarak verilebilir.

Umûmu'l-belvâda varid olan haber-i vâhidin delil olarak kabul etmeyen âlimler, kendi görüşlerini birçok naklî gerekçelerle de temellendirmektedirler. Bu âlimlerin öne sürdükleri gerekçelerden bazısı cevaplarılyla beraber şu şekilde sıralanabilir:

1. Zulyedeyn hadisi; Peygamber (s.a.v.) dört rekâtlı namazın ikinci rekâtında selam verince Zulyedeyn adındaki sahabi "Ey Allah' ın Peygamberi namaz mı kısaldı yoksa siz mi unutunuz" dedi. Peygamber (s.a.v.), "Zulyedeyn doğru mu söylüyor" diye etrafındakilerine sorar. Onlar da "evet ya Resûlullah" diye cevap verirler. ${ }^{64}$ Haber-i vâhidin umûmu'l-belvâ niteliğindeki konularda delil teşkil etmeyeceğini söyleyen âlimler, Peygamber'in (s.a.v.) kıldırdğı namazın eksikliğine dair bir kişi tarafında verilen haberi yeterli bulmayıp diğer sahabeye sormasını kendi görüşlerine delil olarak ileri sürmüşlerdir. Onlara göre mezkûr durum umûmu'l-belvâ niteliğinde olduğundan dolayı Peygamber (s.a.v.) Zulyedeyn'nin haberiyle iktifa etmemiş ve diğer sahabeye teyid ettirme ihtiyacı duymuştur. Dolayısıyla söz konusu hadis, genelin bilmesi gereken bir hususta tek bir kişinin haberiyle iktifa edilemeyeceğinin bir göstergesidir. ${ }^{65}$

Cumhur, Zulyedeyn hadisinin mezkûr iddianın bir gerekçesi olamayacağını, zira hadiste Zulyedeyn'nin verdiği haberin Peygamber'in (s.a.v.) kendi fiiliyle ilgili olduğunu ileri sürerek cevap vermişlerdir. Cumhura göre burada Peygamber'in (s.a.v.) kendi fiili hakkındaki kanaati söz konusudur. Peygamber (s.a.v.), kendisine verilen haberin kendi kanaatiyle çelişmesi nedeniyle habere temkinle yaklaşmış ve onu teyid etmeye gerek duymuştur. Dolayısıyla buradaki haber ile normal haber arasında bir fark bulunmaktadır. Burada bir ön bilgi söz konusu iken dişarıdan verilen haberde ise böyle bir şey söz konusu değildir. ${ }^{66}$ Bazı rivayetlere göre Peygamber (s.a.v.) sadece Hz. Ebu Bekr ve Hz. Ömer'e haberi teyid ettirmiştir. Cumhur, Peygamber'in (s.a.v.) haber hakkındaki bilgiyi sadece Hz. Ebu Bekr ve Hz. Ömer'e teyid ettirmesi umûmu'l-belvâya dair haber-i vâhidin kabulüne ilişkin bir delil olduğunu iddia etmektedirler. Onlara göre haberin sadece iki kişiye teyid ettirilmesi onu haber-i vâhid kategorisinden çıkarmamaktadır. ${ }^{67}$

Ayrıca şunu da söylemek mümkündür: Peygamber'in (s.a.v.) arkasında namaz kılan sahabenin tamamı O'nun dört rekâtlı namazın ikinci rekâtında selam verdiğini müşahede etmelerine rağmen sadece bir sahabi itiraz etmiş ve diğerleri sükût etmiştir. Bu ise herkesi ilgilendiren bir konuda haber-i vâhidin kabul edileceği hususu, sahabe tarafından bilindiğinin bir göstergesidir. Zira sahabe, herkesi ilgilendiren bir hususta tek kişinin vereceği haberin geçersiz olduğu kanaatine sahip olsaydı, onlar da Zulyedeyn'e iştirak edeceklerdi. Dolayısıyla onların sükûtu, herkesi ilgilendiren bir hususta varid olan haber-i vâhid ile amel edileceğinin bir delildir.

2. İsti'zân (eve girmek için müsaade isteme) hadisi; Rivâyete göre Ebû Saîd el-Hudrî şöyle buyurmaktadır: "Ben Medine'de Ensâr meclislerinin birinde bulunuyordum. Ebû Mûsâ (el-Eş'arî) korkmuş bir halde bize geldi. Neyin var diye sorduk. (Ebû Mûsâ) şöyle dedi: “Hz. Ömer kendisine gelmem için haber yolladı. Ben kapısına geldim ve üç kere kapıyı çaldım, cevap alamayınca geri döndüm. Hz. Ömer (onun geri döndüğünü görünce peşinde birini göndererek dönmesini istedi. Ebû Musa el-Eş'arî geri dönünce) "senin bize gelmeni alıkoyan şey nedir" dedi. Bunun üzerine dedim ki size geldim üç defa kapıda selam verdim (kapıyı çaldım) cevap alamayınca geri döndüm, zira Peygamber (s.a.v.) şöyle buyurdu: "Sizden biriniz ü̧̈ kere izin isteyince kendisine izin verilmezse geri dönsün" dedim. (Hz. Ömer) bir şahit getirmezsen seni cezalandırırım (أوجتكانك) dedi." Bunun üzerine Ubey b. Kab, bu topluluğun en küçüğü onunla (Ebû Mûsâ ile) gidecek dedi. (Ebû Said) bu

\footnotetext{
63 Şîrâzî̀, et-Tebṣıra, 315; İbn Akîl, el-Vâdıh fì uṣûli'l-fiḳh, 4/393; Abdulkerîm b. Alî en-Nemle, el-Muhezzzeb fi 'ilmi'l-uṣûli'l-fikhhi'lmukâren (Riyad: Mektebetü'r-Rüşt, 1420/1999), 2/804-805.

64 İmam Mâlik, el-Muvatța', "Salât", 58; Şâfiî, el-Müsned, 1/320 (No. 330); Ebû Abdullâh Muhammed b. İsmâîl el-Buhârî, elCâmi 'u'ș-șahîhh, thk. Muhammed Zuheyr b. Nâsır (b.y.: Dâru Tavki'n-Necât, 1422/2001), “Ezân”, 68 (No. 714).

${ }^{65}$ Cessâs, el-Fuṣ̂ll fi'l-uṣ̂ul, 3/115.

${ }^{66}$ Ebû Ya'lâ el-Ferrâ', el- 'Udde, 3/860. Geniş bilgi için bk. Yiğit, İlk Dönem Hanefì Kaynaklara Göre Ebû Hanîfe'nin Usûl Anlayışında Sünnet, 301-303.

${ }^{67}$ Ebû Nasr Tâcuddîn Abdulvehhâb b. Alî b. Abdilkâfî es-Subkî, el-ïbhâc fî̀ şerhi'l-Minhâc, thk. Ahmed Cemâl ez-Zemzemî Nûreddîn Abdulcebbâr Sağîrî (b.s.: Dâru'l-Buhûs li'd-Dirâsâti'l-İslâmiyye, 1424/2004), 5/1880; İbn Emîru Hâc, et-Takrîr ve'ttahbîr, 2/273-274.
} 
topluluğun en küçüğü benim dedim. (Ubey b. Kab bana) onunla birlikte git dedi." 68 Umûmu'l-belvâ niteliğindeki konularda haberi vâhidin merdûd olduğunu söyleyen âlimler bu rivayeti kendi iddialarını ispatlamak için bir gerekçe olarak ileri sürmüşlerdir. Onlara göre Hz. Ömer'in izin isteme meselesinde Ebû Mûsâ el-Eşarî'nin haberiyle iktifa etmemesi ve kendisinden başka bir şahit getirmesini talep etmesinin nedeni bu meselesinin umûmu'l-belvâ niteliği taşıdığından dolayıdır. ${ }^{69}$ Dolayısıyla onlara göre Hz. Ömer'in bu tavrı umûmu'l-belvâ vasfını haiz konularda haber-i vâhidin kabul edilemeyeceğinin bir göstergesidir.

Cumhûr, ise Hz. Ömer'in söz konusu meselenin umûmu'l-belvâ niteliği taşıdığı için Ebû Mûsâ elEşarî'den şahit getirmesini talep etmediğini, sadece bazı durumlarda daha ihtiyatlı davranılması gerektiğini göstermek için bir şahidin getirilmesini talep ettiğini, zira Hz. Ömer'in birçok meselede haber-i vâhidi kabul ettiğini ifade etmişlerdir.70 Örneğin Hz. Ömer, Abdurrahmân b. Avf'ın Mecusiler hakkındaki şu rivayetini kabul etmiştir: Hz. Ömer Mecusileri zikrederek “Onlara (cizye hususunda) ne yapacağımı (nasıl davranacağımı) bilmiyorum" dedi. Bunun üzerine Abdurrahmân b. Avf "Şehadet ederim ki Allah Resûlü (s.a.v.) "Onlara ehli kitâb muamelesini yapın" buyurduğunu işitim" dedi. ${ }^{71}$ Örnekte görüldüğü gibi Hz. Ömer Abdurrahmân b. Avf'ın şahitliği ile yetinmiş ve ikinci bir şahidin getirilmesini talep etmemiştir. ${ }^{72} \mathrm{~Hz}$. Ömer'in kendi görüşünü bırakıp Dahhâk b. Süfyân'ın "Peygamber (s.a.v.) kendisine Eşyem ed-Dabâbî'nin diyetinden eşine miras verilmesini yazdığı"73 şeklindeki rivayetiyle amel etmesi de onun umûmu ilgilendiren bir konuda haber-i vâhid ile amel ettiğinin bir göstergesidir. Rivayete göre Hz. Ömer, maktulün eşi onun diyetinden pay alamayacağını, diyetin âkileye ${ }^{74}$ ait olduğunu yani âkile arasında paylaşılacağını söyleyince Dahhâk b. Süfyân mezkûr rivayette bulunur. Bunun üzerine $\mathrm{Hz}$. Ömer kendi görüşünü bırakıp hadis ile amel etmiştir.

Cumhur, isti'zân hadisini haber-i vâhidin umûmu'l-belvâ niteliğindeki konularda varid olmama şartını koşanların aleyhine bir delil olduğunu zira Abdurrahmân b. Avf'ın yalnız şahitlik etmesi, hadisi haber-i vâhid kategorisinden çıkarmadı ğını beyan etmişlerdir. Zira iki kişinin haberi de haber-i vâhid bünyesinde değerlendirilmektedir. Dolayısıyla mevzubahis olay, Hz. Ömer'in herkesi ilgilendiren hususlarda haber-i vâhid ile amel ettiğinin bir delilidir. ${ }^{75}$

Umûmu'l-belvâ niteliğine sahip olan konularda haber-i vâhidi delil olarak kabul etmeyen âlimler aklî ve naklî delilerin yanı sıra icmâ' ile de delil getirmişlerdir. Bu âlimler Hz. Ebû Bekr'in cedde/nine mirası hususunda Muğîre b. Şu'be "Allah'ın Resulünden nineye altıda bir verileceğini işittim." şeklindeki rivayetiyle yetinmeyerek kendisinden şahit talep etmesi ve diğer sahabenin buna sese çıkarmamaları neticesinde bu hususta icmâ‘ meydana geldiğini söylemişlerdir. Yukarıda geçen isti'zân meselesinde de icmâ''n meydana geldiğini belirtmişlerdir. Zira o meselede de herhangi bir sahabenin Hz. Ömer'in tavrına karşı çıkmamıştır. Onlar, sahabenin mezkûr olaylara farklı bir tepkide bulunmayıp sükût etmeleri onların icmâ'en bunu kabul ettikleri anlamına geldiğini belirtmişlerdir. ${ }^{76}$

Cumhur buna şöyle cevap vermektedir: Şayet Hz. Ebû Bekr ve Hz. Ömer bu hususta onlardan sadece mütevâtir haber kabul etseydiler söylenen şey doğru kabul edilirdi. Fakat onların iki kişiden gelen rivayetleri kabul etmeleri bu umûmu'l-belvâya dair konularda varid olan haber-i vâhidin kabul edilemeyeceği hususunda icmâ'ın meydana geldiğinin söylenemeyeceğini belirtmişlerdir. Yukarıda da geçtiği gibi iki kişinin rivayeti de haber-i vâhid kapsamında değerlendirilmektedir.77 Dolayısıyla $\mathrm{Hz}$. Ebû Bekr ve Hz. Ömer'in iki kişinin rivayetiyle yetinmeleri ve sahabenin de buna sükût etmeleri, haber-i vâhidin umûmu'l-belvâda merdûd olduğunu iddia edenlerin aksini ortaya koymaktadır.

\footnotetext{
${ }^{68}$ Ebu'l-Hüseyn Müslim b. el-Haccâc b. Müslim el-Kuşeyrî, el-Câmi 'u'ṣ-șahîhh (Ṣahîhh-i Müslim), nşr. Muhammed Fuâd Abdulbâkî (Beyrut: Dâru İhyâi't-Türâsi'l-“Arabî, ts.), "İsti'zân”, 33.

${ }^{69}$ Cessâs, el-Fuṣ̂l fi'l-uṣ̂ul, 3/117.

${ }^{70}$ Ebu'1-Hüseyn el-Basrî, el-Mu temed, 2/139; Şî̂âîi, et-Tebșıra, 313; Cüveynî, et-Telhîs, 2/341-342; Serahsî, el-Ușûl, 1/331. Mâzerî, Îdâhu'l-mahṣ̂ull, 455-456.

${ }^{71}$ Mâlik b. Enes, el-Muvatța', "Zekât", 42.

${ }^{72}$ Sem'ânî, Kavâti 'u'l-edille, 1/156.

${ }^{73}$ Ebû Abdurrahmân Ahmed b. Şu'ayb en-Nesâî, es-Sünenü'l-kubrâ, thk. Hasan Abdulmun'im Şelebî (Beyrut: Müessesetu'rRisâle, 1421/2001), "Ferâiz", 20 (No. 6329).

74 Âkile; öldürülen kişinin diyetini ödemekle sorumlu olan katilin akrabaları. Bk. Muhammed 'Amîm el-İhsân el-Müceddidî Bereketî, et-Ta 'rîfâtu'l-fikhiyye (Beyrut: Dâru'l-Kutubi'l-'Ilmiyye, 1424/2003), 142.

75 Ebu'l-Hüseyn el-Basrî, el-Mu 'temed, 2/169; Kelvezânî, et-Temhîd, 3/62; Âmidî, el-ịhkâm, 2/113.

76 Ebu'l-Hüseyn el-Basrî, el-Mu 'temed, 2/169; Râzî, el-Mahṣ̂ul, 4/442.

77 Ebu'l-Hüseyn el-Basrî, el-Mu 'temed, 2/169; Râzî, el-Mahṣ̣̂l, 4/442.
} 
Başka bir ifadeyle Hz. Ebû Bekr ve Hz. Ömer'in iki kişinin verdikleri haberi kabul etmeleri, sahabenin de sükût etmesi umûmu'l-belvâya dair konularda haber-i vâhidin kabul edileceği hususunda varid olan bir icmâ'dır.

3. Umûmu'l-belvâda varid olan hadis ile amel edilemeyeceğini iddia eden âlimlerin getirdikleri naklî delillerden biri de İbn Abbâs'ın, Ebû Hureyre'nin ateşte pişen bir şeyin yenmesinden dolayı abdestin gerekli olduğu hususunda rivayet ettiği hadisi reddetmesidir. Ebû Hureyre, Peygamber'in (s.a.v.) şöyle buyurduğunu rivayet etmektedir: "Pekmezden az bir şey dahi olsa ateşin temas ettiği şeyde (ateşte pişirilen bir şey yenildiğinde) abdest gereklidir." İbn Abbâs mezkûr hadisi Ebû Hureyre'den işitince "Biz yağdan ve sıcak sudan ötürü abdest mi alırı??"78 söyleyerek onun rivayetini reddetmektedir. Bu âlimler, İbn Abbâs'ın mezkûr hadisi reddetmenin gerekçesi, haberin umûmu'l-belvâ niteliğindeki bir konuda varid olmasından dolayı olduğunu ifade etmişlerdir. ${ }^{79}$

Cumhur mezkûr iddiaya şöyle cevap vermiştir: İbn Abbâs söz konusu hadisi, herkesi ilgilendiren bir konuda varid olduğundan dolayı reddetmemiştir. İbn Abbâs'ın mezkûr hadisi reddetmesinin nedeni, onun Peygamber'in (s.a.v.) ateşte pişen şeyleri yedikten sonra abdest almadan namaz kıldığ yönündeki rivayetine binaendir. Zira İbn Abbâs merfu' olarak şu hadisi rivayet etmektedir: "Peygamber (s.a.v.) koyun küreğinden yedikten sonra abdest almadan namaz kıldı."80 Dolayısıla Ebû Hureyre'nin rivayet ettiği hadisin reddedilmesinin nedeni umûmu'l-belvâya dair bir konuda varid olduğundan değil, onun mensûh olduğuna inanılmasındandır. ${ }^{81}$ Cumhura göre İ̉n Abbâs'ın Ebû Said el-Hudrî'nin riba'l-fadıl (tartılan veya ölçülen bir şeyin kendi cinsi karşılığında ziyadesiyle satılması) konusunda rivayet ettiği hadisi kabul etmesi, onun umûmu'l-belvâda varid olan haber-i vâhid ile amel ettiğinin bir delilidir. ${ }^{82}$

\section{SONUÇ}

Usûl âlimleri umûmu'l-belvâ niteliğine sahip olan konularda haber-i vâhidin delil değeri hususunda farklı görüşlere sahiptirler. Bu husustaki ihtilafın ana nedeni, umûmu'l-belvâ niteliğindeki bir konuda varid olan haberin nakli ile onun bilgisine duyulan ihtiyaç arasında zorunlu bir bağın var olup olmamasıdır. Başta İsâ b. Ebân ve muteahhir Hanefî âlimleri olmak üzere bazı usûl âlimlerine göre haberin nakli ile onun bilgisine duyulan ihtiyaç arasında zorunlu bir bağ bulunmaktadır. Dolayısıyla herkesi ilgilendiren ve bilmesine ihtiyaç duyulan bir konuda varid olan haber-i vâhid delil kabul edilemez. Zira herkesin bilgisine ihtiyaç duyduğu konularda Peygamber'in (s.a.v.) onları aydınlatmakla görevlendirildiği için onun söz konusu durumlarda sınırlı sayıda insanlara haber vermesi düşünülemez. Bu âlimler aklî gerekçelerle birlikte birçok hadis ve eserle de düşüncelerini temellendirmeye çalışmışlardır. Ancak karşıt görüşteki âlimler, bunların delil olarak zikrettikleri bu hadis ve eserlerin de haber-i vâhid kapsamında olduğunu iddia etmişlerdir. Usûl âlimlerinin büyük çoğunluğu ise umûmun bilmesine ihtiyaç duyduğu tüm haberlerin aynı kategoride olmadığını, buna bağılı olarak her haberin nakli ile onun bilgisine duyulan ihtiyaç arasında zorunlu bir bağ olmadığını öne sürmüşlerdir. Cumhur, dinin esasları ve güneşin tutulması gibi âdeten yaygınlık kazanması zorunlu olan haberlerde nakil ile bilgi arasında bir zorunluluğun olduğunu söylemişlerdir. Ancak fer ‘̂̂ konularda böyle bir zorunluluğun olmadığını beyan etmişlerdir. Zira kıyas gibi zannî bilgi ifade eden ve haber-i vâhide nispeten fer" konumunda olan kıyas ile istidlal edilen bir durumda haber-i vâhid ile amel etmek evleviyetle kabul edilmelidir. Cumhûr, herkesi ilgilendiren ve herkes tarafından bilgisine ihtiyaç duyulan konularda olsun veya olmasın Allah (c.c.) haber-i vâhid ile insanları ibadet ile mükellef tutmayı aklen mümkün olduğunu bu hususta aklî ve naklî gibi herhangi bir mânianın da olmadığını belirtmişlerdir

Şunu belirtmek de önemli bir husustur: Umûmu'l-belvâya dair konularda varid olan haber-i vâhid ile amel edilemeyeceği düşüncesinin Ebû Hanife ve öğrencileri Ebû Yûsuf ile Muhammed b. Hasan eş-

\footnotetext{
78 Ebû Îsâ Muhammed b. Îsâ et-Tirmizî, es-Sünen, thk. Beşşâr 'Avad (Beyrut: Dâru'1-Garbi'l-İslâmî, 1998), “Tahâret”, 58 (No. 79 ).

${ }^{79}$ Cessâs, el-Fuṣ̂ul fi'l-uṣ̂ul, 3/119.

80 İmam Mâlik, el-Muvatța', "Tahâret”, 5.

${ }^{81}$ Ebû Muhammed Alî b. Ahmed b. Saîd b. Hazm el-Endelüsî el-Kurtubî. el-ịhkâm fì uṣulli'l-ahkâm (Beyrut: Dâru'l-Kutubi'l'İlmiyye, ts.), 1/155.

82 İbn Hazm, el-ịhkâm, 1/156; İbnü'n-Neccâr, Şerḥu'l-Kevkebi'l-münīr, 2/373. İbn Abbâs'ın riba'l-fadıl hususunda tavrı hakkında farklı iki görüş aktarılmaktadır. Görüşün birine göre İbn Abbâs, daha önce riba'l-fadılın mubah olduğuna dair görüşünü bırakarak Ebû Said el-Hudrî'nin rivayetiyle amel etmiştir. Diğer görüşe göre İbn Abbâs bu rivayetle amel etmemiş ve riba'lfadlın mubah olduğu yönünde görüş bildirmiştir. Semerkandî, Mîzânu'l-uṣ̂ul, 494; Âmidî, el-ĭhkâm, 3/97; İbnü'n-Neccâr, Şerhu'l-Kevkebi'l-münīr, 2/373
} 
Şeybânî'ye nispet edilmesi gerçeği yansıtmamaktadır. Söz konusu düşüncenin İsâ b. Ebân ile ortaya çıkmış ve Kerhî ile son dönem Hanefî âlimleri tarafından kabul görmüştür. Mezkûr düşünce sınırlı sayıda da olsa diğer mezheb müntesipleri tarafından da savunulmuştur.

\section{KAYNAKÇA}

Âmidî, Ebü'l-Hasen Seyfuddîn Alî b. Muhammed b. Sâlim. el-lịnkâm fî̀ uṣ̂li'l-ahkkâm. thk. Abdurrazzâk Afîfî. 4 Cilt. Beyrut: el-Mektebu'l-İ̇lâmî, 2. Basım, 1402.

Apaydın, H. Yunus. “Haber-i Vâhid”. Türkiye Diyanet Vakfı İslâm Ansiklopedisi. 14/355-363. İstanbul: TDV Yayınları, 1996.

Aydın, Ahmet. “Bir Hadis Tenkid Kriteri Olarak Umûmü’l-Belvâ Kavramı”, Kilis 7 Aralık Üniversitesi İlahiyat Fakültesi Dergisi 5/9 (Aralık 2018), 361-398.

Bâcî, Ebû'l-Velid Süleyman b. Halef. İhkâmu'l-fusûl fì ahkâmi'l-usûll. thk. Abdulmecid et-Türkî. b,y.: Dâru'l-Ğarbi'l-İslâmî, 1415/1995.

Bağdâdî, Ebûbekir Ahmed b. Ali b. Sabit Hatip. el-Fakîh ve'l-mütefakkih. thk. Ebû Abdirrahmân Âdil b. Yûsuf el-Garâzî. 2 Cilt. Suudi Arabistan: Dâru İbni'l-Cevzî, 2. Basım, 1421.

Bereketî, Muhammed 'Amîm el-İhsân el-Müceddidî. et-Ta'rîfâtu'l-fikhiyye. Beyrut: Dâru'l-Kutubi'l'İlmiyye, 1424/2003.

Buhârî, Alâuddîn Abdulazîz b. Ahmed b. Muhammed. Alâuddîn Abdulazîz b. Ahmed b. Muhammed. Keş̧ü'l-esrâr fì şerhi Ușûli'l-Pezdevî. b.y.: 4 Cilt. Dâru'l-Kitâbi'l-İslâmî, ts.

Buhârî, Ebû Abdullâh Muhammed b. İsmâîl, el-Câmi 'u'ṣ-ṣahîh. thk. Muhammed Zuheyr b. Nâsir. 9 Cilt. b.y.: Dâru Tavki'n-Necât, 1422/2001.

Cessâs, Ebû Bekir Ahmed b. Alî er-Râzî. el-Fuṣ̂ul fi'l-uṣ̂ul. thk. Ucayl Câsim en-Neşemî. 4 Cilt. Kuveyt: Vizâretu'l-Evḳâf, 2. Basım, 1414/1994.

Cüveynî, İmâmü'l-Haremeyn Ebu'l-Me‘âlî Abdulmelik b. Abdillâh b. Yûsuf. el-Burhân fì uṣulli'l-fikh. thk. Abdulazîm ed-Dîb. 2 Cilt. Mısır: Dâru'l-Vefâ, 5. Basım, 2012.

Cüveynî, İmâmü'l-Haremeyn Ebu'l-Me'âlî Abdulmelik b. Abdillâh b. Yûsuf. et-Telhîs fì ușûlli'l-fikh. thk. Abdullah Culim en-Nebâlî - Beşîr Ahmed el-Ömerî. 3 Cilt. Beyrut: Dâru'l-Beşâiri'l-İslâmî, ts.

Debûsî, Ebû Zeyd Abdullâh b. Ömer b. Îsâ. Takvîmu'l-edille fì uṣ̂uli'l-fikh. thk. Halîl Muhyiddîn eiMeys. Beyrut: Dâru'l-Kutubi'l-'İlmiyye, 1421/2001.

Devserî, Müslim b. Muhammed b. Mâcid. 'Umûm'l-belvâ dirâsetün nazariyyetün tatbîkryyetün. Riyad: Mektebetü'r-Rüşd, 1420/2000.

Ebu'l-Hüseyn el-Basrî, Muhammed b. Alî b. Tayyib. el-Mu temed fì uṣ̂uli'l-fikh. thk. Halîl el-Miss. Dâru'l-Kutubi'l-'İlmiyye, 1043.

Ebu'l-Me'âlî, Şemsuddîn Muhammed b. Abdirrahmân b. el-Ğazzî. Divânu'l-İslâm. thk. Seyyid Kesrevî Hasan. 4 Cilt. Beyrut: Dâru'l-Kutubi'l-'İlmiyye, 1411/1990.

Ebû Ya'lâ el-Ferrâ', el-Kâdî Muhammed b. el-Hüseyn b. Muhammed. el-'Udde fî ușûli'l-fikh. nşr. Ahmed b. Ali Seyr el-Mübârekî. 5 Cilt. b.y.: y.y, 2. Basım, 1410/1990.

Ebyârî, Alî b. İsmâil es-Sanhâcî. et-Tahkîk ve'l-beyân fi şerhii'l-Burhân fi uṣ̂uli'l-fikhh. thk. Alî b. Abdurrahmân Bessâm el-Cezâirî. 4 Cilt. Kuveyt: Dâru'd-Diyâ, 1434/2013.

Emîr Pâdişâh, Muhammed Emîn b. Mahmûd el-Buhârî. Teysîru't-Tahrîr. 4 Cilt. Misır: Mustafâ el-Bâbî el-Halebî, 1351/1932.

Fîrûzâbâdî, Ebu't-Tâhir Mecduddîn Muhammed b. Yakûb. el-Kâmûsü'l-muhịt. thk. Komisyon. Beyrut: Müessesetu'r-Risâle, 8. Basım, 1426/2005.

Gazzâlî, Hüccetü'l-İslâm Ebû Hâmid Muhammed b. Muhammed b. Muhammed b. Ahmed et-Tûsî. elMenhâul min ta 'lîkâti'l-uṣ̂ul. thk. Muhammed Hasan Heyto. Beyrut: Dâru'l-Fikr el-Mu'âsır, 1419/1998. 
Gazzâlî, Hüccetü'l-İslâm Ebû Hâmid Muhammed b. Muhammed b. Muhammed b. Ahmed et-Tûsî. elMustașfâ fí 'ilmi'l-uṣûl. thk. Muhammed Abdusselâm Abduşşâfî. Beyrut: Dâru'l-Kutubi'l-'İlmiyye, 1413/1993.

Hatîb el-Bağdâdî, Ebû Bekr Ahmed b. Alî b. Sâbit. el-Fakîh ve'l-mütefakkih. thk. Ebû Abdirrahmân Âdil b. Yûsuf el-Garâzî. 2 Cilt. Suudi Arabistan, Dâru İbni'l-Cevzî, 2. Basım, 1421.

İbn Akîl, Ebu'l-Vefâ Alî b. Akîl b. Muhammed. el-Vâdıh fì uṣ̂uli'l-fiḳh. Abdullâh b. Abdulmuhsin etTürkî. 5 Cilt. Beyrut: Müessesetu'r-Risâle, 1420/1999.

İbnu'l-Arabî, Ebû Bekr Muhammed b. Abdillâh b. Muhammed el-Meâfirî. el-Mahṣ̂ul fî ușûli'l-fikh, thk. Hüseyn Alî - Saîd Fûde (Uman: Dâru'1-Beyârik, 1420/1999.

İbn Emîru Hâc, Ebû Abdillâh Şemsuddîn Muhammed b. Muhammed b. Muhammed el-Halebî. etTakrîr ve't-tahbîr. 3 Cilt. Beyrut: Dâru'l-Kutubi'l-'İlmiyye, 2. Basım, 1403/1983.

İbn Hazm, Ebû Muhammed Alî b. Ahmed b. Saîd b. Hazm el-Endelüsî el-Kurtubî. el-İhkâm fì ușûli'lahkâm. 2 Cil. Beyrut: Dâru'l-Kutubi'l-'ỉlmiyye, ts.

İbn Hazm, Ebû Muhammed Alî b. Ahmed b. Saîd b. Hazm el-Endelüsî el-Kurtubî. el- 'Irâb 'ani'l- hîreti ve'l-iltibâs el-mevcûdeyn fì mezzâhibi ehli'r-rey ve'l-kiyâs. thk. Muhammed b. Zeynilâbidîn Rüstem. 3 Cilt. Riyad: Dâru'1-Edvâi's-Selef, 1425/2005.

İbn Kudâme, Muvaffakuddîn Abdullah. Ravżatü'n-nâżır ve cünnetü'l-münâzır fì ușûli'l-fikh 'alâ mežhebi'lİmâm Aḥmed. 2 Cilt. b.y.: Müessesetu'r-Reyyân li't-Tibâ‘ ve'n-Neşr ve't-Tevzî́, 2. Basım, 1423/2002.

İbn Mâce, Ebû Abdillâh Muhammed b. Yezîd el-Kazvînî. es-Sünen (Sünenü İbn Mâce). thk. Şu'ayb elArnaût vd. 5 Cilt. Beyrut: Dâru'r-Risâle el-'Alemiyye, 1430/2009.

İbn Manzûr, Muhammed b. Mükerrem. Lisânu'l-'Arab. 18 Cilt. Beyrut: Dâru İhyâi't-Türâsi'l-'Arabî ve Müessestu't-Târîhi'l-'Arabî, 1996.

İbnü'n-Neccâr, Muhammed b. Ahmed b. Abdulazîz b. Alî el-Fütûhî. Şerhu'l-Kevkebi'l-münīr. thk. Muhammed Zuhayl - Nezîr Hamâd. 4 Cilt. Riyad: Mektebetu'l-'Ubeykân, 1413/1993.

İbnu's-Sââtî, Ebu'l-Abbâs Muzaferuddîn b. Alî. Bedî 'u'n-Nizâm (Nihâyetu'l-vuṣ̂ul ilâ 'ilmi'l-uṣûl). thk. Sa'd b. Mehdî es-Sülemî, 2 Cilt. Mekke: Câmi 'atu Ummu'l-Kurâ, 1405/1985.

İmam Mâlik, Ebû Abdillâh Mâlik b. Enes b. Mâlik b. Ebî Âmir el-Asbahî. el-Muvaț̣a'. nşr. Muhammed Fuâd Abdulbâkî. Beyrut: Dâru İhyâi't-Türâsi'1-'Arabî, 1406/1985.

Karâfî, Ebu'l-Abbâs Şihâbuddîn Ahmed b. İdrîs b. Abdirrahmân. Şerhu Tankîhi'l-fusûl. thk. Tâhâ Abdurraûf Sa'd. b.s.: Şeriketu't-Tibâ'eti'l-Fenniyyeti'l-Muttahide, 1393/1973.

Kelvezânî, Ebü'l-Hattâb Mahfûz b. Ahmed b. el-Hasen. et-Temhîd fì uṣ̂uli'l-fikh. thk. Mufîd Muhammed Ebû Amşe - Muhammed b. Alî b. İbrâhîm. Câmi'atu 4 Cilt. Ümmü'l-Kura: Merkezu Bahsi'l-İlmiyyi ve İhyâi't-Turâsi'l-İslâmî, 1406/1985.

Mâlik b. Enes, Ebû Abdillâh Mâlik b. Enes b. Mâlik b. Ebî Âmir el-Asbahî el-Yemenî. el-Muvatța'. nşr. Muhammed Fuâd Abdulbâkî. Beyrut: Dâru İhyâi't-Türâsi'l-'Arabî, 1406/1985.

Mâzerî, Ebû Abdillâh Muhammed b. Alî b. Ömer et-Temîmî. Îdâhu'l-mahṣ̂ul min Burhâni'l-uṣ̂ull. thk. Ammâr et-Tâlibî. Tunus: Dâru'1-Garbi'l-İslâmî, 1421/2001.

Müslim, Ebu'l-Hüseyn Müslim b. el-Haccâc b. Müslim el-Kuşeyrî. el-Câmi 'u'ṣ-șahîh (Șahîhh-i Müslim). nşr. Muhammed Fuâd Abdulbâkî. 5.Cilt. Beyrut: Dâru İhyâi't-Türâsi'l-'Arabî, ts.

Nemle, Abdulkerîm b. Alî. el-Muhezzzeb fi 'ilmi'l-uṣ̂uli'l-fikhi'l-mukâren. 5 Cilt. Riyad: Mektebetü'r-Rüşt 1420/1999.

Nesâî, Ebû Abdurrahmân Ahmed b. Şu'ayb. es-Sünenü'l-kubrâ. thk. Hasan Abdulmun'im Şelebî. 12 Cilt. Beyrut: Müessesetu'r-Risâle, 1421/2001.

Ömer, Ahmed Muhtâr Abdulhamîd. Mu 'cemu'l-Luğati'l- 'Arabiyyeti'l-Mu 'âṣır. 4 Cilt. Kahire: 'Âlemu'lKutub, 1429/2008. 
Pezdevî, Ebu'l-Hasan Ebu'l-Usr Alî b. Muhammed. Kenzü'l-vüṣ̂ul ilâ ma'rifeti'l-uș̂ul. Karaçi: Mir Muhammed Kütüphanesi Merkez-1 İlim ve Adâb, ts.

Râzî, Ebû Abdillâh Fahruddîn Muhammed b. Ömer b. Hüseyn. el-Mahṣ̂ul fì 'ilmi'l-uṣ̂uli'l-fikh. thk. Tâhâ Câbir el-‘Alvânî. 6 Cilt. Beyrut: Müessesetu'r-Risâle, 3. Basım, 1418/1998.

Sem‘ânî, Ebü'l-Muzaffer Mansûr b. Muhammed b. Abdilcebbâr et-Temîmî el-Mervezî. Kavâti 'u'l-edille fi'l-uṣ̂ul. thk. Muhammed Hasan İsmâîl eş-Şâfiî. 2 Cilt. Beyrut: Dâru'l-Kutubi'l-'İlmiyye, 1418/1999.

Semerkandî, Ebû Bekr Alâuddîn Muhammed b. Ahmed. Mîzânu'l-uṣ̂ul fî netâ'ici'l- 'ukûl. thk. Muhammed Zekî Abdulberr. Katar: Metâbi 'u'd-Devha el-Hadîse, 1404/1984.

Serahsî, Şemsü'l-eimme Muhammed b. Ahmed b. Ebî Sehl. el-Mebsût. 30 Cilt. Beyrut: Dâru'l-Ma'rife, 1414/1993.

Serahsî, Şemsü'l-eimme Muhammed b. Ahmed b. Ebî Sehl. el-Ușûl. thk. Ebü'l-Vefâ el-Efgânî. 2 Cilt. Beyrut: Dâru'l-Marife, ts.

Subkî, Ebû Nasr Tâcuddîn Abdulvehhâb b. Alî b. Abdilkâfî. el-ïbhâc fî şerhi'l-Minhâc. thk. Ahmed Cemâl ez-Zemzemî - Nûreddîn Abdulcebbâr Sağ̂îî. 7 Cilt. b.s.: Dâru'l-Buhûs li'd-Dirâsâti'lİslâmiyye, 1424/2004.

Şâfiî, Ebû Abdullâh Muhammed b. İdrîs. el-Müsned (Müsnedu'ş-Şâfi î̀). thk. Mâhir Yâsîn Fahl. 4 Cilt. Kuveyt: Şeriketu Ğirâs li'n-Neşri ve't-Tavzî', 1425/2004.

Şâfiî, Ebû Abdullâh Muhammed b. İdrîs. er-Risâle. thk. Ahmed Muhammed Şâkir. Mısır: Matba'atu Mustafâ el-Bâbî el-Halebî, 1358/1940.

Şeybânî, Ebû Abdillâh Muhammed b. el-Hasen. el-Hucce 'alâ ehli'l-Medîne. thk. Mehdî Hasan el-Kîlânî el-Kâdirî. 4 Cilt. Beyrut: 'Âlemu'l-Kutub, 3. Basım, 1403.

Şeybânî, Ebû Abdillâh Muhammed b. el-Hasen. Muvaț̣a'ü'l-İmâm Mâlik rivâyetü Muhammed. thk. Abdulvahhâb Abdullatif. b.y.: el-Mektebetu'l-İlmiyye 2. Basım, ts.

Şîrâzî, Ebû İshâk İbrâhîm b. Alî b. Yûsuf el-Fîrûzâbâdî. Şerhư'l-Luma'. thk. Abdulmecîd et-Türkî. Beyrut: Dâru'l-Garbi'l-İslâmî, 1408/1988.

Şîrâzî, Ebû İshâk İbrâhîm b. Alî b. Yûsuf el-Fîrûzâbâdî. el-Luma' fi usûli'l-fikh. thk. Alî Abdulazîz. Kuveyt: Cem 'iyetu İhyâi't-Turâsi'l-İslâmî, 1407/1987.

Şîrâzî, Ebû İshâk İbrâhîm b. Alî b. Yûsuf el-Fîrûzâbâdî. et-Tebșira fì uṣûli'l-fiḳh. thk, Muhammed Hasan Heyto. Dımaşk: Dâru'l-Fikir, 1400/1980.

Şûşâvî, Ebû Abdillâh Hasan b. Alî b. Talha er-Recrâcî. Refu'n-nikâb an Tenkîhi'ş-Şihâb. thk. Ahmed b. Muhammed es-Serrah - Abdurrahman b. Abdillah ec-Cibrîn. 6 Cilt. Riyad: Mektebetu'r-Ruşd, $1425 / 2004$.

Teftâzânî, Sa'duddîn Mes'ûd b. Fahriddîn Ömer b. Burhâniddîn. Şerhu't-telvîh ala't-Tavdîh. 2 Cilt. Misır: Mektebetu Sabîh, ts.

Tirmizî, Ebû Îsâ Muhammed b. Îsâ. es-Sünen. thk. Beşşâr 'Avad. 6 Cilt. Beyrut: Dâru'l-Garbi'l-İslâmî, 1998.

Tûfî, Ebu'r-Rebî‘ Necmuddîn Süleymân b. Abdilkavî b. Abdilkerîm. Şerhu Muhtașari'r-ravża. Abdullah b. Abdulmuhsin et-Türkî. 3 Cilt. Beyrut: Müessesetu'r-Risâle, 1407/1987.

Urmevî, Safiyyuddîn Muhammed b. Abdurrahmân el-Hindî. Nihâyetu'l-vuș̂ul fi dirâyeti'l-ușûl. thk. Sâlih b. Süleymân - Saîd b. Sâlim es-Süveyh. 9 Cilt. Mekke: el-Mektebetu't-Ticâriyye, 1416/1996.

Üsmendî, Ebu'l-Feth Alâuddîn Muhammed b. Abdilhamîd. Beżlü'n-nazar fi'l-ușûl. Muhammed Zekî Abdulberr. Kahire: Mektebetu't-Turas, 1412/1992.

Yiğit, Metin. İlk Dönem Hanefì Kaynaklara Göre Ebûu Hanîfe'nin Usûl Anlayışında Sünnet. İstanbul: İz Yayıncllık, 2009. 
Zebîdî, Ebu'l-Feyz Muhammed el-Murtazâ b. Muhammed. Tâcu'l-'arûs min cevâhiri'l-Kâmûs. thk. Komisyon. 40 Cilt. b.y.: Dâru'l-Hidâye, ts.

Zerkeşî, Bedruddîn Muhammed b. Behâdır. el-Bahru'l-muhị̂t fì uṣ̂uli'l-fiḳh. 8 Cilt. b.y.: Dâru'l-Kutubî, $1414 / 1994$. 